\title{
Musical Nuances and the Aesthetic Experience of Popular Music Hooks: Theoretical Considerations and Analytical Approaches
}

Bernhard Steinbrecher

University of Innsbruck, Department of Music, Innsbruck, Austria steinbrecher.bernhard@gmail.com

Recepción: septiembre 2020. Aceptación: diciembre 2020.

\begin{abstract}
This article discusses the concept of musical nuances from a process-oriented perspective, with a particular emphasis on the aesthetic experience of hooks in Western popular music. First, the text elaborates on the particularities of nuances from the perspective of cognitive psychology. Second, it highlights their importance for musical interpretation, characterization, memorization, and valuation. Third, it critically reflects on analytical approaches to rhythmic and melodic nuances and gets into alternative methods to analyze such microscopic subtleties in the context of musical hooks. Fourth, analytical examples examine nuance-related intricacies in song phrases as processes regarding the aesthetic experience of increasing and decreasing intensity, tension, and motion. Finally, the findings and theoretical considerations are discussed in the broader context of mainstream popular music analysis.
\end{abstract}

Keywords: Rhythmic nuances, melodic nuances, process-oriented analysis, aesthetic experience, popular music hooks

\section{Los matices musicales y la experiencia estética de los hooks de la música popular: consideraciones teóricas y enfoques analíticos}

\section{Resumen}

Este artículo discute el concepto de "matices musicales" desde una perspectiva procesual, con particular énfasis en la experiencia estética de los hooks en la música popular occidental. En primer lugar, el texto desarrolla 
las particularidades de los matices desde la perspectiva de la psicología cognitiva. En segundo lugar, destaca su importancia para la interpretación, caracterización, memorización y valoración musical. En tercer lugar, reflexiona críticamente sobre los enfoques analíticos de los matices rítmicos y melódicos e introduce métodos alternativos para analizar tales sutilezas microscópicas en el contexto de los hooks musicales. En cuarto lugar, los ejemplos analíticos examinan las complejidades relacionadas con los matices en frases de canciones como procesos relativos a la experiencia estética de la intensidad, tensión y movimiento crecientes y decrecientes. Finalmente, los hallazgos analíticos y las consideraciones teóricas se discuten en el contexto más amplio de la interpretación del mainstream de la música popular.

Palabras clave: matices rítmicos, matices melódicos, análisis de procesos, experiencia estética, hooks de música popular

\section{Nuances musicais e a experiência estética dos popular music hooks: considerações teóricas e abordagens analíticas}

\section{Resumo}

Este artigo discute o conceito de nuances musicais numa perspetiva orientada para o processo, com particular ênfase na experiência estética dos popular music hooks ganchos na música popular ocidental. Em primeiro lugar, o texto desenvolve as particularidades das nuances a partir da perspetiva da psicologia cognitiva. Em segundo lugar, destaca a sua importância para a performance musical, caracterização, memorização e apreciação. Em terceiro lugar, reflete criticamente sobre as abordagens analíticas de nuances rítmicas e melódicas e introduz métodos alternativos para analisar tais subtilezas microscópicas no contexto de music hooks ganchos musicais. Em quarto lugar, os exemplos analíticos examinam as complexidades relacionadas com as nuances das frases canções como processos relacionados com a experiência estética de intensidade, tensão e movimento crescentes e decrescentes. Finalmente, os resultados analíticos e as considerações teóricas são discutidos no contexto mais amplo da interpretação da música popular mainstream.

Palavras-chave: nuances rítmicas, nuances melódicas, análise orientada para o processo, experiência estética, popular music hooks 


\section{Starting point}

Music analysis is nowadays a widely-used method in the interdisciplinary field of popular music studies. For examining Western popular music, scholars often apply rather conventional methods of harmony, melody, form, and rhythm analysis, but also approaches using physical-acoustic measurement methods, such as waveforms and sonograms, are becoming more numerous. Whereas the sounds of classic rock, progressive rock, and the Beatles long have been in the center of analytical attention, there is a growing number of research analyzing as well specific currents of, e.g., electronic dance music (EDM), hip-hop, and funk. Comparatively little attention has been paid, though, to internationally successful songs which reached the upper echelon of top 40 charts since the beginning of the new millennium (cf., e.g., von Appen et al., 2015; Peres, 2016; De Clercq, 2020). ${ }^{1}$ In this article, I lay a particular focus on this research subject, and I attach it to the idea of mainstream popular music.

Mainstream popular music is certainly a complex and hard-to-define term (e.g., Toynbee, 2002; Martel, 2011; Huber, 2013; Taylor et al., 2013; Baker, 2013; Weisbard, 2014; Jost, 2016), and it is out of the scope of this article to theorize in detail its overall specifics. From a music-oriented perspective, however, there are some particular scholarly and everyday-language accounts which I consider helpful in framing an operative term to discuss musical nuances and their analysis.

Basically, mainstream popular music is very popular popular music, striving for maximum popularity with the largest part of the listening public. It is tied strongly to shifting musical, cultural, technological, and other trends and developments, and probably the most obvious sign that a song has reached a mainstream status is when it is listed in top positions on all-genres' singles charts, calculated by sales and streams.

The concept of the mainstream often functions ideologically, to declare opposition against, e.g., the authentic, honest, creative, and subversive (Huber, 2013, p. 8) or the '"mainstream' of commercial taste, wherever that might lie" (Frith, 1998, p. 66). Notions of commerciality are inherently interwoven with the idea of mainstream popular music, in that it is viewed negatively as highly commercial music raising suspicion that it was created solely out of

\footnotetext{
${ }^{1}$ In some articles, musicologists take these kind of songs as representative examples to discuss new analytical conceptualizations (e.g., Attas, 2015; Spicer, 2017; Forrest, 2017; Adams, 2019; Duinker, 2019). A broad repertoire of Billboard Hot 100 songs is examined by Scholz (2014) and Richards (2017).
} 
economic interests. Hence, the term triggers specific beliefs as to why and how certain music is made. Seen from this angle, the discursive attribution "mainstream" does not necessarily point to particular (musical or other) aesthetics, but it rather relates to an imaginary conception of particular intentions and production practices within capitalistic conditions. This becomes apparent when considering some common musical characterizations of mainstream popular music, all of which more strongly allude to (assumptions of) how the music was produced rather than to its inherent aesthetic qualities: It carries the image of being polished, pre-processed, cut- and-dried, overproduced, and removed of any edge whatsoever.

Technological aspects must be ascribed an important role in this regard. Since the beginning of the digital era of Western popular music production, quantization tools and vocal correction software have been used widely to eliminate tempo deviations and imprecise pitches caused by humans' performance, in order to ensure aesthetics of regularity and in-tuneness. In contemporary music production, particularly in the field of charts-oriented pop, EDM, and hip-hop, respective post-production reworking is often no longer necessary. Because in many cases, the music's basic beat patterns are created by a "click \& drag" principle, i.e., by entering events into the regular piano roll grid of a digital audio workstation (DAW), using ready-made sounds and snippets provided by presets and sound libraries.

Around this computerized frameworks, which also entail a change from auditory-based to visually/screen-based creation and recording, new aesthetic questions arise, e.g., as to dealings with notions of imprecision, tension, and live(li)ness in electronically mediatized music, which require analytical consideration in connection to microrhythmic and microtonal subtleties.

Generally, the approaches presented in this article strive to foster an integrated perspective on "nuances" in the context of Western tonal music, i.e., in regard to music where they are not implemented at system level. They will be discussed in connection to subtle processes that happen within tone-to-tone successions in fundamental building blocks of mainstream popular music on a phrase level, also referred to as "hooks".

\section{Conceptualization of musical nuances}

Nuances are fine-grained particulars happening at music's micro-level. They might be thought of as slight variations within a categorical structure that occur, for example, in the form of little deviations from discrete 
pitch, interval, meter, or beat categories (Snyder, 2000, p. 86 and p. 143; Clarke, 1987, p. 22). More generally, nuances can be viewed as referring to tone-internal processes and tone-to-tone relationship details that must be ascribed an important role in the interpretation, characterization, memorization, and aesthetic experience of music.

According to theories from cognitive psychology, musical nuances, i.e., "those features of musical experience that are too subtle to be captured within our analytical grids" (Higgins, 1997, p. 87), are perceived and verbalized differently from established notions of harmony, melody, and rhythm (Thies, 1982, p. 33; Raffman, 1993, pp. 83-91; Crowder, 1993, pp. 134-135; de la Motte-Haber, 1996, pp. 478). What harmony, melody, and rhythm have in common is that they represent conceptual categories based on culturally specific consensuses about the organization of perceptual parameters. Such frameworks, such as the 12-tone grid or the concept of meter and bars, are characterized by constant and relatively fixed proportional relationships between single parameters. They enable the listener to identify certain musical patterns and, thus, create certain musical expectations (Snyder, 2000, p. 195). ${ }^{2}$ For example, Western popular music has established its own categorial sub-frameworks throughout its history, mostly within the superordinate framework of Western musical culture. Particular harmonic progressions, melodic principles, metrical structures, and -building on that- formal models have become characteristic of certain periods of styles, as several musicological studies about historical developments and genre-related specificities have analyzed. ${ }^{3}$

As opposed to discrete entities of harmony, melody, and rhythm, the tonal and temporal subtleties of nuances are more difficult to categorize conceptually. Similar to further parameters of music's sonic reality (Wicke, 2003, p. 20) -like timbre, texture, loudness, and tempo- ${ }^{4}$ nuances usually are not limited or fixed, but continuous (Snyder, 2000, pp. 87-88). Their cognitive representation is viewed as more analogous to perception and stimulus than symbolic, abstract-categorical representations, i.e., they seem to be more strongly connected to immediate physical experiences

\footnotetext{
${ }^{2} \mathrm{~A}$ basic example of such a symbolic, abstract-categorical representation is the recognition of a Cmajor chord, which at first must be classified, consciously or unconsciously, as a triad in a majorminor system with a specific tuning before it can be contextualized into broader frameworks. By going through this process, one can estimate whether a certain note sounds "right," "unusual," or "wrong" in a certain context.

${ }^{3}$ See, e.g., Moore (1992), Bowman (1995), Budde (1997), Pfleiderer (2006), Butler (2006), Everett (2009), Elflein (2010), von Appen and Frei-Hauenschild (2012), Temperley and de Clercq (2013), Scholz (2014), Doll (2017).

${ }^{4}$ See, e.g., Middleton (1990), Pfleiderer (2006), Tagg (2012), Steinbrecher (2016), Brockhaus (2017).
} 
and are more likely to be stored in episodic, rather than semantic, memory. In our perception of these sound dimensions, relative categories of "more" or "less" play an important role. Usually, we try to describe them either with the help of close-to-the-body adjectives -in the form of metaphorical opposite pairs like "loud" / "quiet", "pushing" / "pulling”, "bright" / "dark", "fast" / "slow", and "hard" / "soft" (Thies, 1982)- or, given that we have the respective vocabulary, through production aspects, e.g., instruments, devices, effects, and software.

\section{Relevance of nuances}

Musical nuances are worthy of attention for several reasons. First, they lie at the heart of artistic interpretation as "fine-grained deviations [...] that a performer [fluidly] manipulates to enhance a performance" and "allow for new and varied interpretations of familiar music" (Bugos et al., 2014, p. 207). Used in this context, the term interpretation refers to "what might be called 'management of nuances'” (Snyder, 2000, pp. 88-89). Nuances are highly relevant for the characterization of individual, distinct manners of playing and singing. According to Bugos et al., listeners develop "preferences for specific performers based on characteristics of musical nuance" (2014, p. 207). Throughout the history of popular music, one probably can find numerous examples of musicians being worshipped for their idiosyncratic handling of nuances, often in connection with the ability to play or sing strongly in a bodily oriented way, with "feel" rather than technical proficiency (cf., e.g., Green, 2002). The strong relationship between nuances and music's expressive and emotional qualities already has been addressed, partly, in music psychology (see, e.g., Juslin, 1997; Lindstrom et al., 2003; Geringer and Sasanfar, 2013).

Second, cognitive psychologists indicate nuances' relevance in contributing to a "sense of musical life" (Sloboda, 2005, p. 73) to the performance of conventionally notated music, in adding a "human touch" (Hennig et al., 2012, p. 1) to computer generated perfect beat patterns, and in hearing "human performances rather than the 'dead-pan' renditions of computers" (Juslin, 2003, p. 274). ${ }^{5}$ The latter two notions become specifically important in regard of dealings with modern digital music technology, even more so when considering opposite notions as to the "inhuman pitch accuracy"

\footnotetext{
${ }^{5}$ Sloboda is concerned about "expressive variation that is present in any musical performance" that is directed toward the categories of pitch and time "enshrined in our notation" but "are unlikely to be capable of reliable transcription by ear" nor is it conventional notation "up to the task of recording [them]". Thus, he obviously talks about what I have framed as nuances throughout this article.
} 
(Moylan, 2020, p. 77) of vocal performances caused by the erasure of microtonal inflections through auto-tune -a particular effect that is used extensively in current rap productions.

Third, due to their strong connection to one's own episodic memory, nuances may help the listener connect music to autobiographical actions and, thus, relate it to personal experiences and contexts. In "Musical Musical Nuance" (2010), philosopher Tiger C. Roholt critically discusses Diana Raffman's nuance (perceptual) ineffability claim (see Raffman, 1988, p. 688). By pointing to William E. Kennick (1961), Roholt elaborates on the possibilities of indirect description, including metaphor and comparison, for the effable rendering of musical nuances. According to Roholt, a musical nuance -"typically defined as a note performed slightly raised or lowered in pitch or slightly early or late in time" (Roholt, 2010, p. 1)- can hardly be described directly in terms of music-theoretic or other concepts (Roholt, 2010, p. 7). Instead, nuances become characterizable through their subtle perceptual effects in musical contexts. The listener can describe nuances indirectly through these effects, which "involves characterizing the circumstances and context in which a feeling is experienced" (Roholt, 2010, p. 3).

Fourth, musical nuances must be ascribed an important role in musical valuation and the aesthetic experience of music. Approaches from experimental aesthetics (Berlyne, 1971; Niketta, 1982; Sloboda and Juslin, 2005 ) indicate that musical judgments built during the listening process are strongly dependent on the degree of complexity and surprise that one finds in the music. A piece of music is perceived as pleasant up to an optimal level of stimulus. For example, in the ear of an average "passive listener" in Austria, ${ }^{6}$ frequent changes in tonality or nested polyrhythms may exceed this level and, as a consequence, the listener probably would categorize the music as too complex. Conversely, if the sounds are very stable and often repeated, the point possibly will be reached at which they don't need to be processed actively anymore because no new information is offered. As a consequence, habituation occurs, and the listener loses interest. Between these two poles lie the appealing sensations of slight instability, inconsistency, and unpredictability caused by nuances, potentially not the least of which because they are usually very short in time. This facilitates immediate perception, but makes them difficult to store in long-term memory. As a result, nuances are difficult to memorize without repeated listening and can be "rediscovered" on recordings more than once (see also Clune, 2013, p. 51).

${ }^{6}$ Classification taken from Huber (2018, pp. 203-205). 


\section{Analytical considerations of rhythmic and melodic nuances}

Microrhythm is a nuance feature that has been examined the most in recent years, from different perspectives and with different understandings, in musicological work about popular music (e.g., Iyer, 2002; Pfleiderer, 2006; Danielsen, 2006 and 2010a; Johansson, 2010; Klingmann, 2010; Frühauf et al., 2013; Kilchenmann and Senn, 2015). Generally, the concept of microrhythm refers to a rhythm's time structure below the smallest "tappable" subdivision of the fundamental beat (see Iyer, 2002, p. 393; Pfleiderer, 2006, p. 347).

From the perspective of record production, William Moylan finds various elements of recording "that make use of microrhythm or microtiming", e.g., delay echoes, dynamic contour of reverb, time- and amplitude-based rhythms of reflections, and dynamic envelope within timbres (2020, p. 201). However, in many musicological studies, microrhythm has been examined from a microtiming perspective. The researchers focus on the onsets of musical events and the distance between them, i.e., their inter-onset intervals. Often, temporal deviations from a static (virtual) metrical grid are analyzed. ${ }^{7}$ The scholars examine whether particular events are being placed slightly before or after equidistantly repeated points in time regularly. These findings are interpreted with regard to the "feeling" and "groove quality" of particular music, shedding light on the question of whether it tends to be felt "laid back" or "pushing forward".

A basic assumption that underlies grid-oriented approaches is that music is being experienced against the backdrop of an evenly ticking inner clock. Some scholars have questioned this somewhat hierarchical thinking. Mark J. Butler remarks that in African music, for example, a repeating, seemingly irregular rhythm pattern often functions as the timekeeper of a piece of music (Butler, 2006, p. 89). Christopher Hasty (1997) views the dichotomic separation between rhythm, as a fluctuating foreground element, and meter, as an invariant background framework, critically and understands meter as a vital phenomenon that can change throughout the listening experience. Christiane Gerischer suggests that rhythmic phenomena generally should not be examined merely from the perspective of (micro) rhythmic deviations from a temporal grid and potential regularities and irregularities, but rather as a kind of "gestalt" in the sense of a rhythmic succession (Gerischer, 2010, p. 16). Anne Danielsen extends the idea of a rhythmic shape in that she draws attention to the fact that the perception

${ }^{7}$ In connection with this, the discrepancies between bass and drums (Butterfield, 2011, p. 3). 
of rhythmic events is influenced by many more factors than just their inter-onset intervals. Thus, she conceptualizes microrhythm as the "overall rhythmic shaping of musical events at the micro level", encompassing timing, duration, shape, timbre, and intensity (2016, p. 2).

The idea of such demarcated musical utterances within the fabric of rhythm allows for further consideration with regard to microrhythmic gestures. According to Danielsen (2010b), the notion of gesture indicates a sounding entity that is communicated to others and, therefore, incorporates the music's cultural dimension. Considering that entities like these can be shaped and sized very differently, they can, among others, occur in the form of microrhythmic gestures that are relatable to the feeling of a piece or segment of music. In this sense, as Pedersen (2009) notes, the meaning of microrhythmic gestures is connected to tiny differences in tone or shade that must be analyzed as aesthetic expressions.

Pedersen's remark on tiny tonal differences points to another important aspect in connection with musical nuances: microtonality. Microtones and microintervals generally refer to "any musical interval or difference of pitch distinctly smaller than a semitone" (Griffiths et al., 2001), i.e., to non-standardized pitches outside the Western chromatic framework. For example, in Western musical culture of the $20^{\text {th }}$ century, composers of so-called "microtonal music" have used microtones conceptually by dividing the octave into more than 12 parts and/or by introducing tunings other than the 12-tone equal temperament (Griffiths et al., 2001). Microtonal subdivisions or unusual instrumental tunings also have been used as core song elements or significant effects by rock bands such as Sonic Youth, King Gizzard \& The Lizard Wizard, Nine Inch Nails, and Radiohead (see Chadwin, 2019), and EDM artists such as Aphex Twin and Sevish (see Hart, 2016). A prominent example of recurrent microtonal variations of a certain (mostly third and seventh) scale degree in blues and jazz concerns the concept of "blue notes" (Kubik, 2013, for a statistical characterization see Cutting, 2018).

However, microtonality in Western popular music typically can be found in momentary, rather than permanent, deviations from the 12-tone framework. As melodic nuances (Snyder, 2000, p. 86), they occur in the form of pitch-bendings, small intonation variations, vibratos, slides, and glides, but they also may gravitate -more unsteadily fluctuating and less target-oriented- around a discrete pitch. In popular music analysis, strong emphasis regarding microtonal particulars has been placed particularly on vocal performances (e.g., Winkler, 1997; Brackett, 2000; Daley, 2007; 
Senn, 2007; Hähnel et al., 2014; Pfleiderer et al., 2015; Herbst et al., 2016). These studies mostly are concerned with individual or genre-specific singing styles, putting them in context with the construction of "personae" and with cultural codes and stereotypes. ${ }^{8}$ But not much attention has been paid to instrumental melodic nuances, and more fundamentally, to the question of how microtonal subtleties might influence the aesthetic experience of tone-to-tone relationships within the temporal succession of song phrases, such as their interplay with rhythmic nuances.

Both rhythmic and melodic nuances must be viewed as an essential part of "small-scale articulation" (Chew, 2001) concerning the (difficult-to-notate) intricacies of how tones start, end, progress, change, and interact (connect or detach) over time in actual musical situations. In this regard, Geoffrey Chew notes that: "Single notes may be articulated and phrases begun by the 'placing' of notes (their being played or sung a fraction late, separated from the preceding note by a brief silence or other agogic device), by an accent (or conversely by an unexpected unaccented note in a loud passage) or other dynamic device, or by nuances of timbre or intonation" (2001).

The high importance of articulation as "cues for the communication of emotional intentions" (Geringer and Sasanfar, 2013, p. 162) has been demonstrated in listening experiments (e.g., Gabrielsson, 1995; Juslin, 1997; Bresin and Friberg, 2000; Geringer et al., 2006). More broadly, articulation has been used as a keyword in relation to, for example, style (Johansson, 2010), musical expression and dynamic correspondence (Godøy, 2010), timbre (Pfleiderer, 2003), gesture (Fay, 1974), rhythm (Hasty, 1997), and microrhythm (Pedersen, 2009). However, particularly in analytical writing about popular music, articulation often pops up as a seemingly important, yet not very extensively examined, sonic attribute. In the following section, I introduce a more comprehensive concept of how to access the small-scale articulatory features of rhythmic and melodic nuances analytically in the context of popular music hooks.

\section{Process-oriented analysis of nuances}

To focus attention on processes within and between such microscopic features generally requires a theoretical rethinking of the analytical approach. This is particularly the case in mainstream popular music, which usually

${ }^{8}$ For the idea of the "persona" see, e.g., Auslander (2009), Moore (2012), Hansen (2019). 
centers around repeated hooks, i.e., short phrases -or, again, "gestures" (Traut, 2005, p. 57)- that unfold within the temporal capacity of shortterm memory. In the analysis of these fundamental building blocks, I suggest extending the rather "architectonical" perspective of traditional music theory and, thus, taking into account more strongly the immediate listening impression and the perception of moment-to-moment successions. ${ }^{9}$ What I am indicating here is what could be called "process-oriented analysis" (Fuß, 2005, p. 22), i.e., analytical approaches that focus on small musical units and the "beguiling charm" that may lie within their boundaries (Thomson, 1983, p. 15); consider the "dynamic, nonreductive, and individuated motion at the note-to-note level as captivating for music lovers" (Narmour, 1992, p. 330); and aim to explain "the particularity and spontaneity of aesthetic experience as it is happening" (Hasty, 1997, p. 3).

The idea of including considerations from cognitive psychology into music analysis most prominently hearkens back to Leonard Meyer's theories about musical expectation and embodied musical meaning $(1956,1973)$. His work contributed to an aesthetic rethinking of how short -and probably discontinuous, unexpected, or ambiguous- parts of a musical piece may influence the listening experience. This is a perspective that sees music's attractiveness not necessarily determined by the virtual entity amalgamating at the end of the listening process. It influenced renowned works on musical texture and the dialectical balance between intensifying and resolving tendencies (Berry, 1987), low-level melodic relations of implication and realization (Narmour, 1990, 1992), and metrical projection (Hasty, 1997). However, with popular music, these scholars are rather short-spoken and dismissive (see Meyer, 1956, pp. 209-214 and p. 239; Berry, 1987, pp. 293-294; Narmour, 1992, p. 202 and pp. 386-389). ${ }^{10}$

As for microtiming aspects, such a process-oriented perspective also goes beyond the aforementioned structural, rhythmic deviation analysis of "groove-based" music, like funk or EDM. Of course, hooks in popular music can sustain a rhythmic groove due to the steady repetition of expressive microtiming (Keil, 1994), but the creation of such a "vital drive" is normally not their primary function (which is, essentially, to "hook" the listener). ${ }^{11}$ Instead, what I want to discuss is the question of how tone-

\footnotetext{
${ }^{9}$ Such an architectonical perspective would favor, for example, analyzing harmony with regard to large-scale functional-structural interrelationships, melody as a function of harmony, and rhythm as to its interrelations with meter.

${ }^{10}$ For a discussion of process-oriented approaches toward popular music, see Steinbrecher 2016 (pp. 104-134)

${ }^{11}$ Charles Keil even makes a distinction between "significant gestures" and the "vital drive", which
} 
to-tone successions and their rhythmic and melodic nuances affect our aesthetic experience of increasing and decreasing intensity, tension, and motion due to fluid processes of anticipation, continuation, expansion, contraction, acceleration, and deceleration. According to the philosophical conception of aesthetic time from Joan Stambaugh, one might speak of temporal tensity within hooks that "works itself out aesthetically in the musical process" (Stambaugh, 1964, p. 278). Thus, their structure can be viewed as forming a process that "constitutes itself in a temporal manner" (Stambaugh, 1964, p. 267) and strives to work (stretch) out, but not necessarily resolve, the tensity created by tone and rhythm (Stambaugh, 1964, pp. 276-278). ${ }^{12}$

Microtonal subtleties can add their share to these processes in that the interplay between "out-of-tune-ness" and being "in tune" generates tension on different levels and with different intensities. Moylan remarks that "flat pitches create tension of anticipation that the performer will reach the target pitch, or a sharp pitch can represent the stress of perceived over exertion" (2020, p. 77). This kind of tension can occur in glides, as well as in simultaneously sounding, sustained pitches that slightly -i.e., around a quartertone-alternate with each other. The tension increases the longer the friction remains unresolved -a process that also may create a sense of incompleteness or, to the contrary, a feeling of arrival when the pitches finally come together. Moreover, subtle deviations in pitch intonation also can fulfill the function of adding direction and motion to a melodic line (Moylan, 2020).

The microrhythmic layout also can contribute to tension processes within a hook. Generally, Gerischer highlights the fact that every elongation or stretching of an impulse in relation to others must be viewed as a kind of emphasis. Once the inter-onset intervals become larger, the respective impulses occupy more space within a structure, thereby attracting more attention. Accordingly, the expansions and contractions within a rhythmic succession delineate an increase and decrease in intensity, which can be interpreted with regard to its effect (Gerischer, 2010, p. 16). Matthew Butterfield has elaborated on this effect, among others, from the perspective of what he calls "motional energy" (2006, p. 4). ${ }^{13}$ He uses Hasty's

they interrupt (Traut, 2005, p. 68).

${ }^{12}$ Rather than a structure that refers to "scaffolding for a house which could be described as large, broad, or rusty" (Stambaugh, 1964, p. 267). She adds that "resolution as the goal of this tensity is secondary. Its prime function and meaning lie in creating the unique and incomparable mode of musical substance" (Stambaugh, 1964, p. 278).

${ }^{13}$ See also Butterfield (2010 and 2011). 
metric projection theory to discuss how expressive microtiming on the note-to-note (and note-to-rest) level can condition the "affective power" of rhythmic propulsion. Unlike other research in this field, Butterfield focuses on successions within individual parts and, moreover, also incorporates the microtiming aspects' interaction with the "syntactical level" of patterns into his considerations. Essential to his approach is a broader concept of anacrusis, sharing Hasty's opinion that anacrusis "represents considerably more than upbeat or pickup; it is rather a special kind of continuation oriented toward a new beginning" (Butterfield, 2006, p. $3)$. Henceforth, Butterfield opens up an important perspective on how to interpret nuance, e.g., regarding durational inequality, in terms of its anacrustic, projective effect on subsequent events and the "energy it carries into [them]" (Butterfield, 2006). ${ }^{14}$ Projections of this kind can contribute to hooks' forward momentum, but may as well work the other way around and induce the perception of deceleration and relaxation (see, e.g., Butterfield, 2010, p. 4).

\section{Methodological considerations}

To analyze notions of rhythmic and melodic nuances in recorded popular music, it is obviously necessary to take an in-depth look at musical material and listen very closely to small details within bounced multi-track mixes. In this section, I provide a short introduction to how I have applied such analyses in practice and reflect on the analytical process as such.

Since nuances are difficult to grasp and impart when using conventional notational methods only, which primarily visualize discrete sonic entities and their relationships (Wicke, 2003, p. 14; see also, e.g., Middleton, 1990 , p. 105), ${ }^{15}$ I conducted my analysis mainly on the basis of physical-acoustic measurement methods provided by software solutions. In particular, I used Sonic Visualizer and Adobe Audition combinatorily. ${ }^{16}$ The decision to work with both programs is due to my personal experience, in that I consider Sonic Visualizer more feasible to extract

\footnotetext{
${ }^{14} \mathrm{He}$ mentions accent and "slurred offbeat articulation" as other possibilities as to how anacrusis is created (Butterfield, 2006).

${ }^{15}$ Additional symbols can be supportive in this regard, but will not be used in the following sections. An early attempt for a taxonomy of additional symbols can be found in Abraham and von Hornbostel (1910).

${ }^{16}$ Nowadays, plenty of easy-to-use and free (or inexpensive) software solutions are available to measure recorded sounds and generate physical visualizations (also, e.g., Audacity and Praat). A good, extensive introduction to working with Sonic Visualizer can be found here: https://charm.rhul. ac.uk/analysing/p9_1.html.
} 
pitch-related information, while Adobe Audition appears to me more intuitive for analyzing aspects of time and for editing. ${ }^{17}$

To address articulatory questions of microrhythm and microtonality, I used both waveforms, which plot the amplitude of an acoustic signal over time, and sonograms, which visualize the temporal succession of the signal's frequency spectrum. Thus, I was able to compare frequency information with the amplitude and, e.g., cut out certain events to analyze them individually.

Such filtering often is necessary in analytical practice, because particularly when confronted with contemporary popular music recordings, the analyst usually must deal with a high density of events within strongly compressed recordings containing many different tracks fused together into a main mix. As a consequence, subtleties in the distribution of spectral energy and details on the articulation of single voices often are difficult to recognize. The analysis can be facilitated when the researcher has access to single tracks of the production, but in this case, one should bear in mind that the "common" listener usually enjoys or dislikes the whole texture of a song, instead of separated, out-of-context instruments or vocals. ${ }^{18}$ Issues of "readability" go hand-in-hand with the challenge of ensuring clarity and discursiveness in communicating analytical findings. In the following section, within the context of my short examples, I present possibilities to complement the computer-generated analytical figures with notational re-transcriptions and my own graphics to accentuate and/or visually simplify certain aspects.

In general, transcriptions of this kind also require critical reflection, both in connection to their role in the analytical process, as well as to the analytical findings one generates with them. A fundamental difference vs. traditional notational methods is that physical-acoustic methods generate transcriptions that are not based on listening impressions. Thus, they (also) need to be interpreted subjectively by the person who is analyzing them and, thus, can influence, change, and enhance the way the scholar is listening to the music in question, e.g., with regard to pitch and rhythm

\footnotetext{
${ }^{17}$ I usually start my analyses with the following sonogram preferences: Adobe Audition: Window Function: Blackman-Harris; Scale: Logarithmic, Spectral Resolution: 4096; Sonic Visualizer: Spectral analysis window shape: Hann; Scale: Logarithmic, Spectral Resolution: 8192, Window Overlap: $93,75 \%$

${ }^{18}$ Normally, a good starting point for the analysis of nuances is to look for a song segment in which the instrumental or vocal voice in question doesn't overlap too much with other elements of the musical fabric. This way, it is possible to define the basic features and transfer the findings to other, probably more densely textured segments. However, it is inevitable that one's own ear and eye act as a controlling instances in this process, ensuring that the sounds remain similar.
} 
perception, and assumptions about how certain sounds are generated (Stockmann, 1979, p. 221). Therefore, working with such tools must be viewed as a learning process as well (see also Winkler, 1997, pp. 199-200; Pfleiderer, 2006, p. 32).

\section{Analytical examples}

Through the following short, analytical examples, I highlight some different aspects and forms of nuance usage in the hooks of contemporary mainstream popular music that might be worthy of further, more extensive consideration. ${ }^{19}$ This includes tiny offset-anticipations in piano sequences, subtly nested asymmetrical synthesizer rhythms, a flattened percussive shuffle pattern, the inner dynamics and anacrustic impact of ascending vocal and instrumental slides, and articulatory variations within vocal hooks with regard to contract-and-stretch effects. The analyses also aspire to provide guidance on how to approach and communicate nuances conceptually in a qualitative methodical setting.

The first two examples concern nuance discontinuities and deviations in piano hooks from international pop hits "7 Years" (Lukas Graham, 2015) ${ }^{20}$ and "Hymn for the Weekend" (Coldplay, 2015). ${ }^{21}$ These piano-tone successions reveal microrhythmic characteristics whose effects I would describe as slipping and stumbling into an unsteady pendulum movement. As for the mid-tempo ballad "7 Years" of Danish band Lukas Graham, the hook under examination establishes the song's melodic fundament right at its introduction. However, during the first few times I listened to the record, I encountered some (more or less) subtle tempo fluctuations throughout the unfolding melody that affected, i.e., slightly irritated, my bodily entrainment to the music. To make my audible impression visually comprehensible, I created a waveform and a sonogram of the first few seconds of the song using Adobe Audition software, magnifying the first 20 seconds in particular. Subsequently, I tried to pin down, as closely as possible, the actual duration of the tones by taking the frequency spectrum as a basis to measure the onsets and offsets within the amplitude. To make

\footnotetext{
${ }^{19}$ Most of the examples initially were picked without a particular focus on nuances. My interest for the discussed subtleties arised through a more holistic, reception-oriented analysis and interpretation of the songs and artists.

${ }^{20}$ Lukas Graham. 2015. 7 Years. On Lukas Graham (Blue Album) [MP3 file]. Copenhagen Records. Amazon.com Song ID: 258893583.

${ }^{21}$ Coldplay. 2015. Hymn For The Weekend. On A Head Full Of Dreams [MP3 file]. Parlophone. Amazon. com Song ID: 264335469.
} 
the relationship between the tones comprehensible and be able to play them back through midi, I then chose a rather unconventional way to re-transcribe the measured milliseconds into traditional notional values using Musescore software. ${ }^{22}$

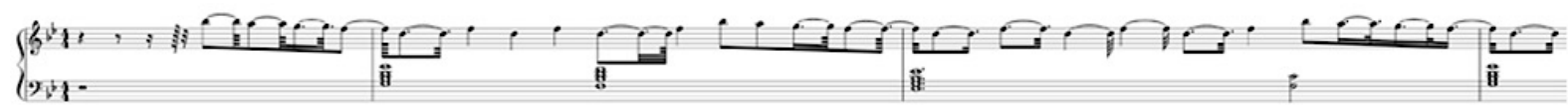

Figure 1. The opening piano hook of "7 Years" (0:00,0-0:12,8; see also Appendix 1).

The analysis indicates that the song's engineers/producers certainly did not use quantization methods to eliminate imprecisions from the live recording, at least not those of the piano. Adjacent piano tones, which conventionally would be notated as straight eighth or quarter notes, subtly vary in duration from each other. Durational inequities are the most apparent in the third bar, when singer/piano player Lukas Forchhammer delays the melody's progression by elongating the second $\mathrm{D}$ and $\mathrm{F}$ tones, and making the subsequent $\mathrm{D}$ about $100 \mathrm{~ms}$ shorter. This is a clearly audible stylistic device in the performance that induces the feeling of physical and mental backpedaling in preparation for the main start of the song.

More subtle deviations can be found at the descending anacrustic figure $\mathrm{Bb}-\mathrm{A}-\mathrm{G}-\mathrm{F}$, in which the third tone $\mathrm{G}$ is remarkably shorter than the other tones. This deviation happens in the first four out of five of the respective downward movements in the opening hook; thus, it is a recurring effect that may be described figuratively as coming down a children's slide and slipping into the pendulum movement of the subsequent bar. ${ }^{23}$ The lengthened fourth tone $\mathrm{F}$ of the sequence attenuates, in principle, this acceleration by stretching the melodic cell over the bar's boundaries. However, the Gm chord in the accompanying bass interrupts this temporal compensation in that it is played straight on the bar's first beat. As a result, the downbeat chord and the downbeat melody tone D are slightly displaced, making the perception of the downbeat accent rather blurry,

\footnotetext{
${ }^{22}$ In the case of 7 Years, the length of a bar/whole note is two seconds; thus, its proportional tone durations are $1000 \mathrm{~ms}$ (half notes), $500 \mathrm{~ms}$ (quarter notes), $250 \mathrm{~ms}$ (eighth notes) up to $8 \mathrm{~ms}$ (256th notes). Peter Winkler, in his transcription of Aretha Franklin's voice, presented, with a rather frustrated undertone, a somehow similar approach in trying to notate rhythmic relationships in more detail than usual (1997, pp. 186-188).

${ }^{23}$ To stay in the picture, this movement potentially raises the impression of going up and down on a children's swing. Such a rather semiotic interpretation is strengthen further by the ticking clock in the background, which also stresses the lyrical content of the song that is strongly related to singer Forchhammer's biography. He contemplates the death of his father and, in an optimistic way, the process of getting older with friends, family, and children. The strongly personal emotional narrative of the song particularly resonates through its "piano topic", i.e., imagined bodily engagement with Forchhammer sitting alone at the reverberated instrument.
} 
yet less "incisive". This displacement happens, again, in all four of the analyzed bars, as well as at the transitional second chord in the third bar.

A similar, but more "bumpy", articulation, followed by a melodic pendulum movement, can be observed in the piano hook of Coldplay's song "Hymn for the Weekend".

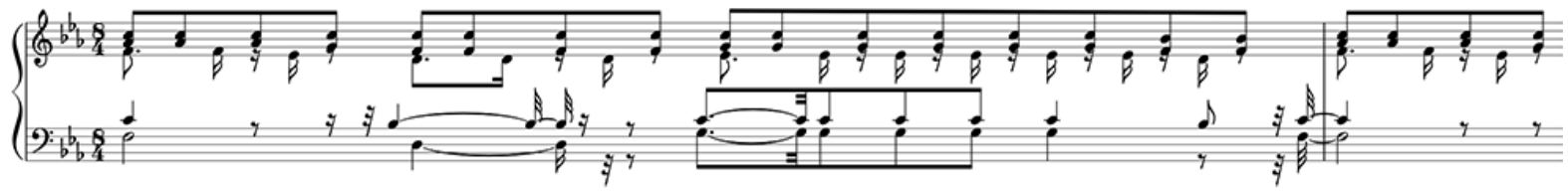

Figure 2. Piano hook of "Hymn For The Weekend" (0:32,2-0:38,5; see also Appendix 2).

Singer/piano player Chris Martin tends to pre-draw certain chord tones shortly in the left hand regularly. These microrhythmic offsets can be seen and heard, for example, in the first bar at note $\mathrm{Bb}$ in the bass, which Martin plays approximately a 32nd note earlier than the corresponding Dm7 chord.$^{24} \mathrm{He}$ also plays the F5 chord at the end of the bar too early, thereby splitting the downbeat of the next phrase literally into two. Martin also strives to reproduce this kind of anticipatory nuance in live performances of the song, in which he strongly imparts his motional affectedness with the hook by jumping up and down on his stool. ${ }^{25}$

Rik Simpson, the song's mix engineer, sees in "Hymn for the Weekend" a hybrid of styles "with strong hip-hop/R\&B elements". ${ }^{26} \mathrm{He}$ particularly hinges this description on the drums in the verses, which he views as "very swung and sample-based". ${ }^{27}$ A significant element of these sections is a fragile, high-frequency "ballpoint-pen-on-glass" percussion

\footnotetext{
${ }^{24}$ According to the hooks' duration, I decided to use a eight-four time signature here and also in figures 3 and 8.

${ }^{25}$ See, e.g., the performance at Radio 1's Big Weekend 2016 (https://www.youtube.com/ watch?v=nm5CiwNluKI, published 29 March 2016). However, it is questionable whether the hook actually is played live. In the second verse of the performance, it definitely is not. A cover version of the song, in which the piano player does not play these offsets, may allow for a comparison of what's missing (https://www.youtube.com/watch?v=uGyCyjCDCq8, published 5 March 2015).

${ }^{26}$ Simpson was interviewed by Paul Tingen for the article "Inside Track: Coldplay 'Hymn For The Weekend"' (Sound on Sound, published March 2016, https://www.soundonsound.com/techniques/ inside-track-coldplay-hymn-weekend). Actually, Chris Martin's stumbling piano playing fits well into the band's well-constructed image of "average persons" regardless of their costly, technically sophisticated productions -e.g., Ryan Bassil, "Why Do We Hate Coldplay?" (Vice, published 11 February 2016, https://www.vice.com/da/article/6w8v44/why-do-we-hate-coldplay).

${ }^{27}$ It isn't mentioned in this interview whether the analyzed glass percussion pattern also was created on the basis of a sample (supposedly it is). However, in live situations, the manual recreation of the pattern is an essential part of the live performance of the song.
} 
pattern that enters at the beginning of the second verse. Rather uncommon for contemporary pop music, it is built upon an up-tempo shuffle beat. The pattern contains a shuffled 16th-note structure that remarkably seamlessly interlocks with the song's mostly even $4 / 4$ groove. One reason for this can be ascribed to the fact that the rhythmic alternations of duration within the shuffle, between long and short notes, are not as big as they would be in an equidistantly triplet subdivision of the beat. The waveforms and sonograms indicate that the even notes tend to be shorter than they would regularly be in a triplet context (approximately $190 \mathrm{~ms}$ instead of $220 \mathrm{~ms}$ ), whereas the uneven notes are regularly over their triplet 16 th-note value (approximately $140 \mathrm{~ms}$ instead of $110 \mathrm{~ms}$ ). Thus, the difference between adjacent tones is only about 50 to 60 milliseconds.

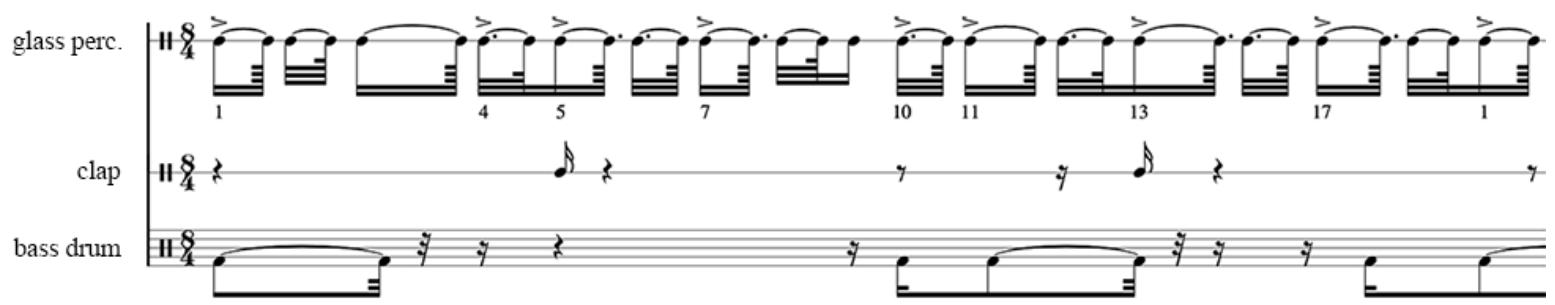

Figure 3. Shuffle pattern from "Hymn For The Weekend" (1:20,3-1:23,2; see also Appendix 3).

This small swing ratio of approximately 1.35:1, which is also in the lower range of average swing ratios measured in jazz research (an overview can be found in Pfleiderer, 2006, p. 264), attenuates, together with the fragile articulation of the glassy strokes, the "triple feel" edginess of the shuffle. It helps interweave the "swung" rhythmic feel, which already is induced at the beginning of the song by the forward momentum created by Martin's anacrustic piano phrasing, softly into the overall texture. The pattern's accentuation structure further supports this subtle interlocking, particularly on accents 4 and 17, which directly anticipate the snare and kick-drum strokes. ${ }^{28}$

The two examples so far have focused mainly on small temporal deviations between adjacent tones, but musical nuances also might be examined beyond that perspective, e.g., by emphasizing subtle rhythm nestings and

${ }^{28}$ The use of such adumbrated groove elements, like the examined shuffle beat, potentially raises questions as to notions of cultural appropriation, particularly against the backdrop of discussions around the song's visual representation -e.g., Colin Stutz, "Coldplay \& Beyoncé's 'Hymn for the Weekend' Sparks Debate About Cultural Appropriation” (Billboard, published 29 January 2016, https:// www.billboard.com/articles/columns/rock/6859394/coldplay-beyonce-hymn-for-the-weekendcultural-appropriation-debate). 
gradations in tonal transitions. The next examples sharpen the focus on hooks from two hits from the field of EDM pop music, in which irregularities in instrumental microtiming normally are rather unlikely due to the predominance of grid-based music making via digital audio workstations. I particularly concentrate on segments from the songs "This One's For You" (David Guetta featuring Zara Larsson, 2016) ${ }^{29}$ and "This Is What You Came For" (Calvin Harris featuring Rihanna, 2016). ${ }^{30}$

At the beginning of "This One's For You", a percussive synthesizer establishes an asymmetrical $3+3+3+3+4$ rhythm pattern seemingly comprising five hits, or single sound events. However, upon closer listening, it turns out that the sound is more multilayered, actually comprising five groups of three events.

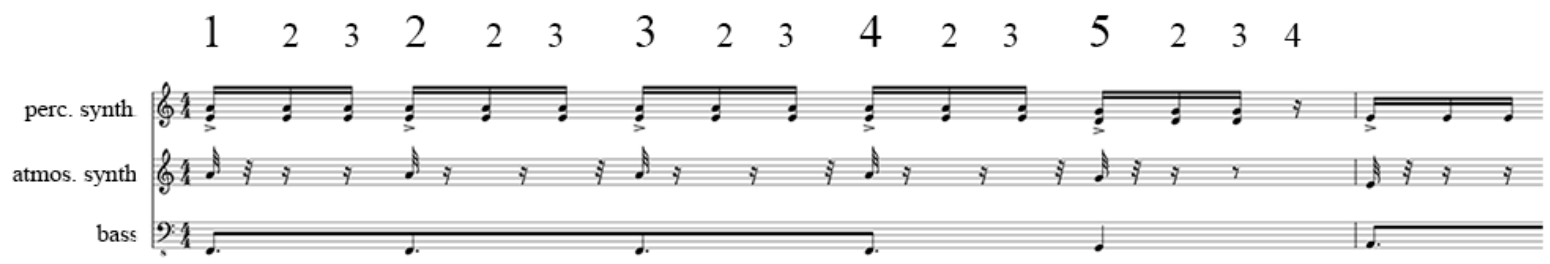

Figure 4. Percussive synth hook from “This One’s For You” (0:02,1-0:04,7; see also Appendix 4).

A delay or related effect repeats every main accent of the pattern two times on a barely audible level, thereby subtly emphasizing the tense, syncopated feel created by the groups of three against the evenly spaced $4 / 4$ meter beats of the kick-drum and bass. These rhythmic nuances become identifiable when the pattern is played back in half-time.

During the first verse of "This Is What You Came For", Calvin Harris similarly dissects a "diatonic" rhythm (see, e.g., Butler, 2006, p. 81-89), which is placed on a steady quarter-note motion. He subdivides the segments of a three-part $3+3+2$ synthesizer pattern into finely surfaced, strongly in-itself-moved arpeggios.

\footnotetext{
${ }^{29}$ David Guetta. 2016. This One's For You (feat. Zara Larsson) [MP3 file]. Parlophone. Amazon.com Song ID: 265595396.

${ }^{30}$ Calvin Harris. 2016. This Is What You Came For (feat. Rihanna) [MP3 file]. Columbia. Amazon.com Song ID: 269708705.
} 


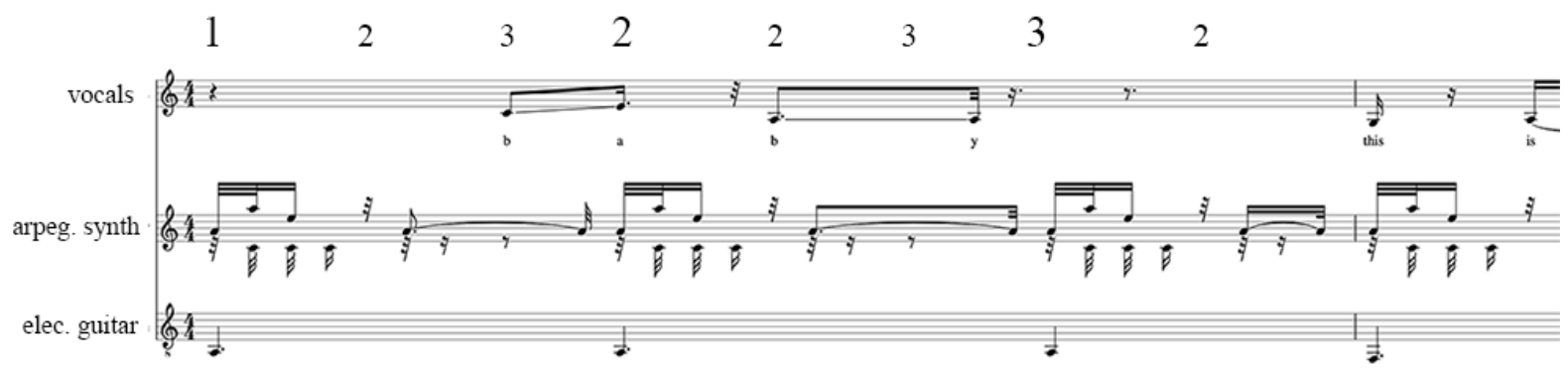

Figure 5. Arpeggio synth hook and vocal slide from "This Is What You Came For" (0:00-0:02,3; see also Appendix 5).

Each arpeggio covers, at least as far as I can approximate through a sonogram analysis, a fairly wide range of 13 scale degrees, unfolding with a brisk tonal background texture. Microrhythmically, the arpeggios constantly push and pull the $3+3+2$ divisions internally through their short-long time-interval structure.

Shortly summarized, Harris and Guetta use microrhythmic segmentations to increase their hooks' rhythmic density by creating two-dimensionally nested patterns. However, in the case of these two examples, the rhythmic tension induced by the metric dissonance of the main, asymmetrical accent patterns already is quite high. According to Scott Murphy, notions of conflict and resolution are pivotal to such patterns, "as the groups of three create tension before giving way to the two-groups, which seem to realign the rhythm with the underlying metre and 'resolve' the metric tension" (Murphy, 2002 in Traut, 2005, p. 62).

Besides rhythmic subtleties, both EDM songs integrate ascending melodic slides at structurally important points, providing an opportunity to integrate melodic nuances in the articulation analysis more strongly. As can be seen in Figure 5, Rihanna starts her vocal line in "This Is What You Came For" by gliding for approximately 250 milliseconds from the lower C to E. Subsequently, she inserts a short rest and roughly jumps down a fifth to the root tone A ("b-a-by"), which she repeats multiple times. According to Eugene Narmour's implication-realization model (1990), the slide potentially changes our melodic expectations. Without it, the duplication of the root tone would realize the implication of reversal after a large interval, thereby creating a rather closural effect. However, by beginning the motive by hoisting a minor third from below the actual starting tone, it becomes a continuous process that introduces rather smoothly into the vocal phrasing and the song. ${ }^{31}$

\footnotetext{
${ }^{31} \mathrm{~A}$ contrary effect is realized at another pivotal structural point in the song, in the middle of the
} 
During the postchorus of "This One's For You", an ascending slide is used to jump-start another synthesizer hook of the song, which sounds like an alienated human voice. ${ }^{32}$

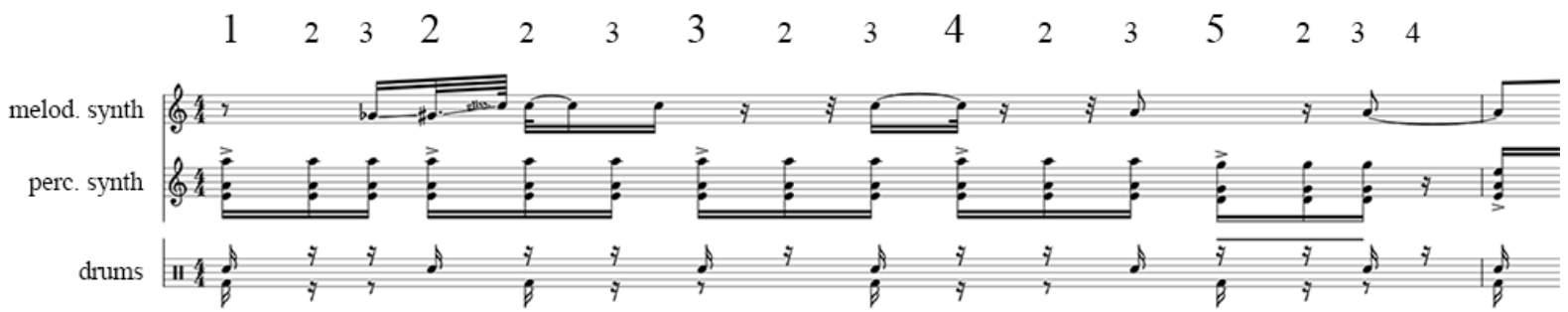

Figure 6. Vocal slide in the postchorus of "This One's For You" (1:07,6-1:10,0; see also Appendix 6).

The slide anticipates the second main accent of the underlying, aforementioned asymmetrical synthesizer pattern by approximately a 32nd note, thereby starting around the same time as the second repetition of the basic pattern's delay. It then moves up only gradually, according to my measurements, about one whole note for the next $70 \mathrm{~ms}$, then quickly raises in pitch to the peak note of $\mathrm{C}$. This accelerating tonal transition, which spans the range of a tritone, might be described metaphorically as a bow-taut rubber band on a slingshot before being fired into the subsequent, stepwise-braking accents. These accents rhythmically work against the $3+3+3+3+4$ basic synthesizer hook, but interlock with the snare drum hits of the dembow rhythm from the drums. The resultant percussive effect is reinforced by the relatively quickly decreasing release phase of the squawking melody tones, which I transcribed in the notation as rests to aid communicative clarity.

With the help of the next examples, I want to elaborate more specifically on nuances in vocals. My particular interest is directed toward vocals that are not sung in a traditional way, i.e., often do not contain clearly distinctive melody lines with discrete "pitch stepping". The first analysis concentrates on the rap part in the first verse of the song "Stressed Out" by the band Twenty One Pilots (2015). ${ }^{33}$ When transcribing rap vocals, musicologists usually do not notate pitch aspects or address in detail the relationship

\footnotetext{
four-measure chorus. Here, a hard melodic cut is implemented where a smooth downward glide would be expected instead. Rihanna closes the first half of the phrase by singing a major seventh above the local harmony Fmaj7 and starts the second half of the phrase with a major sixth below. These two tones are separated by a rest of about a dotted semiquaver, which originates from stopping, or artificially cutting, the sung syllable abruptly.

${ }^{32}$ It was omnipresent throughout the European Championships, functioning as a kind of audio logo.

${ }^{33}$ Twenty One Pilots. 2015. Stressed Out. On Blurryface [MP3 file]. Fueled by Ramen. Amazon.com Song ID: 256212015.
} 
between adjacent tones. Usually, the focus lies in identifying accentuation patterns or indicating whether the rapper uses duple, quadruple, or triplet flows in normal or double time (see, e.g., Duinker, 2019; Ahlers, 2019). Ben Duinker remarks in this context that "further research toward developing analytical methods that account for expressive microtiming in flow would help us better understand the subtleties of relationship between natural speech rhythms and rhythmicised triplet flow" (2019, p. 453).

As for "Stressed Out", a nuance analysis of the first phrase shows the subtle variations and pairings that singer/rapper Tyler Joseph interlaces into his rather linear overall rap delivery. He alternates between short, straightforwardly pronounced monosyllabic words ("I", "wish", "some”), words / assonances with two syllables that he separates ("bet-ter", "e-ver"), and monosyllabic words/rhymes that he stretches out ("f-ou-nd", "sou-nds", "hea-rd"). ${ }^{34}$

The latter monosyllabic words also vary internally in a (micro)tonal sense, as the pitch changes up to about three semitones upward or downward throughout the words' pronunciation. The five-line system clearly reaches its limits in an attempt to visualize this kind of vocal nuance. However, through the process of transcribing such micromelodic successions, it becomes visible how rap performances like those of Tyler Joseph do not necessarily stick to discrete pitches, but rather gravitate around in-between locations.

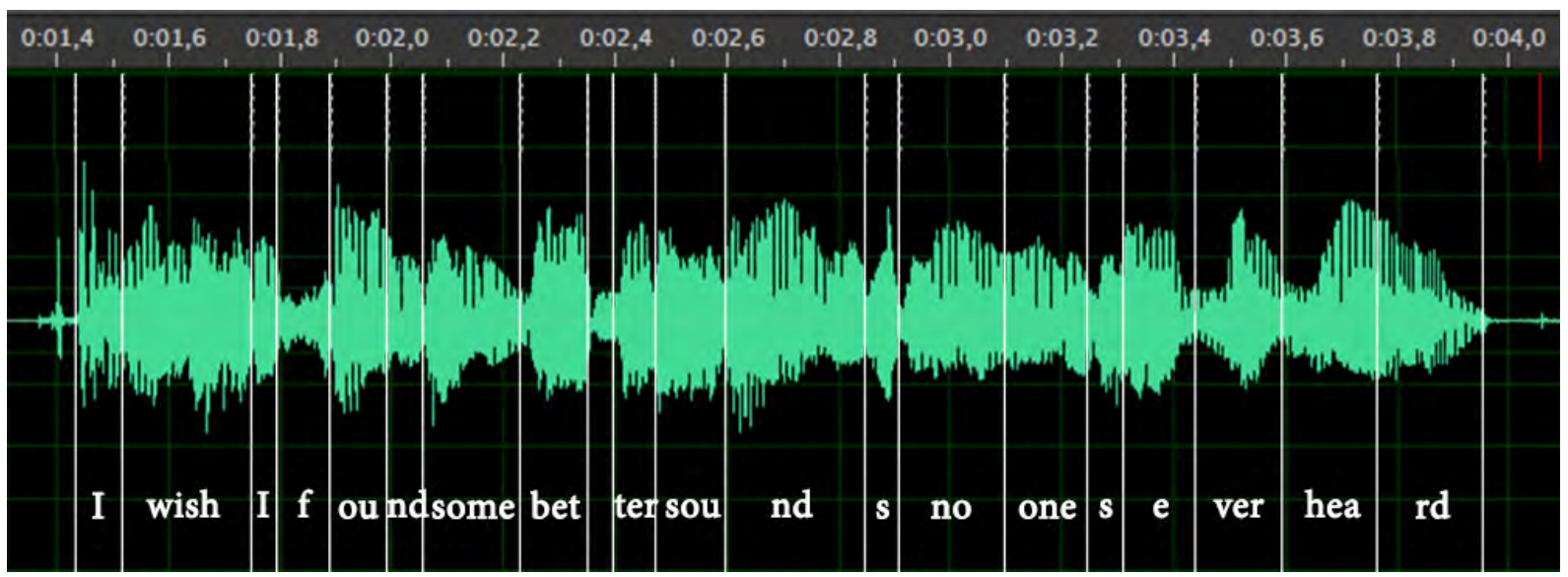

Figure 7. Rap vocal hook in the first verse of "Stressed Out" (waveform) (0:00,0-0:04,2); see also Appendix 7).

\footnotetext{
${ }^{34}$ In this case, a vocals-only version was used in addition to the analysis of the regular recording. The visualization is based on the audio file available at https://www.youtube.com/ watch?v=uw1ng2or7E0 (uploaded 25 March 2017).
} 


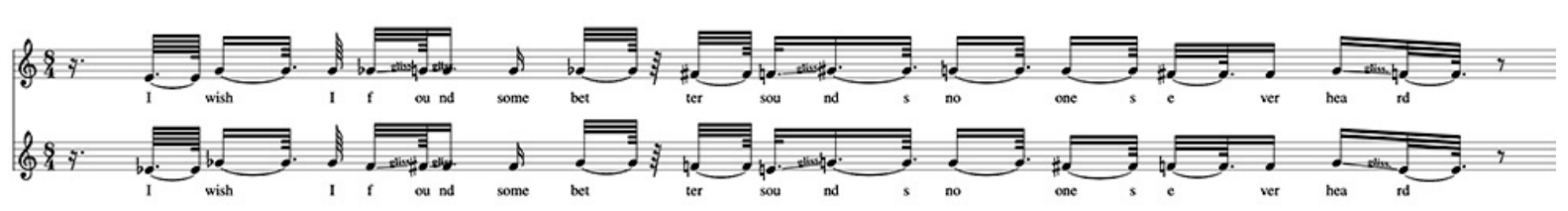

Figure 8. Rap vocal hook in the first verse of "Stressed Out" (notation) (0:00,0-0:04,2).

In the analyzed segment, the pitch cannot be pinned down precisely to, e.g., $\mathrm{E}$ and $\mathrm{Eb}, \mathrm{F}$ and $\mathrm{E}, \mathrm{G}$ and $\mathrm{Gb}$, etc. My notational method for indicating these ambiguities -which cause subtle dissonant friction to the underlying bass tones of F, D, and E- entails making two notations that are slightly altered in pitch.

Of course, rappers are not the only vocalists in popular music whose delivery disturbs our traditional concept of melody and singing. At this point, I shortly want to look beyond the realm of mainstream popular music, at the shouts, screams, or growls in styles such as punk, hardcore, or heavy metal, where the expressive use of (distorted) timbre that usually is more important than clean-cut melodic progressions within a broad ambitus. However, this doesn't necessarily mean that aspects of tonality and melodic nuances must be left out of respective analytical consideration. A spectral analysis of the vocals in the song "Turnover" $(1990)^{35}$ from post-hardcore band Fugazi reveal how singer Guy Picciotto unerringly drifts his melodic motions in the verse phrases up to a whole note up and down the tonal center A. This observation is visualized in the following notation that, like the other examples so far, reduces the listening impression to fundamental tones. ${ }^{36}$

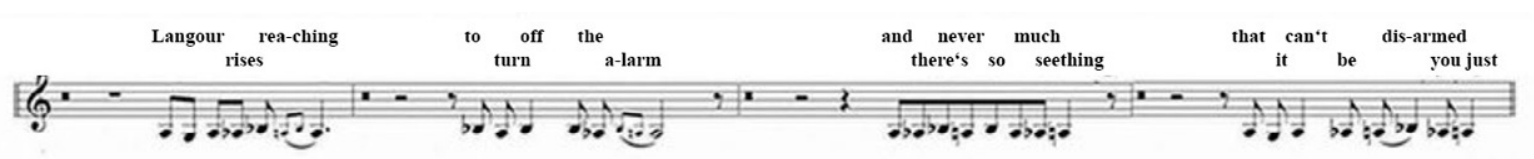

Figure 9. Vocal melodic phrase in the first verse of "Turnover" $(0: 33,8-1: 03,8)$.

The fact that the Western notational system is only capable of visualizing fundamental tones, at least when used in a mostly conventional way, becomes at times restricting, particularly with regard to vocal performances like the ones discussed here. For example, Picciotto regularly emphasizes the first two or three vocal formants more strongly than the fundamental frequencies. However, this must be viewed in connection

\footnotetext{
${ }^{35}$ Fugazi. 1990. Turnover. On Repeater [CD]. Dischord Records. DIS 44.

${ }^{36}$ In the case of this notation, detailed rhythmic and melodic nuances are left out.
} 
with his at-times very speech-like singing, which helps him alternate the articulation within short segments dynamically. Picciotto begins many of his melodic cells with short-attack and "barking" exclamations, and he contrasts these percussive impulses by ending the segments with elongated syllables that contain many slide movements into and away from the aspired note. He does this kind of contract-and-stretch phrasing particularly in the chorus phrase, at first within four short melodic cells that then climax in the long-stretched central word of the song, "turnover". In the following transcription of the chorus's melody line, an alternative visualization of these nuance processes is provided using a method that I call articulation outlining. It is based on sonograms and may help make the nuance characteristic more adequately comprehensible. ${ }^{37}$

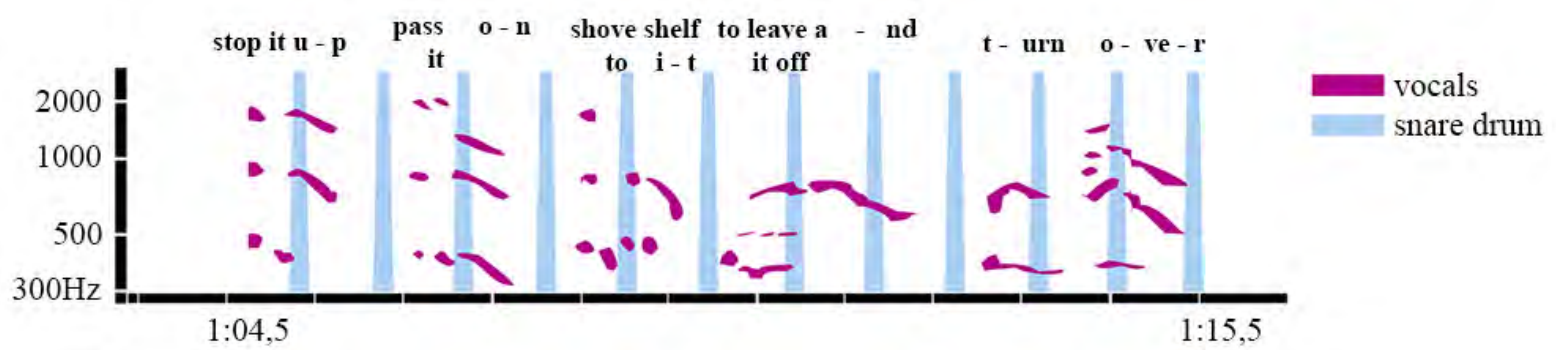

Figure 10. Vocal hook in the chorus of "Turnover" (1:03,8-1:16,0; see also Appendix 8).

The approach that entails using elongated downward articulation to stretch out the tensity created by speech-like hook segments has become a noticeable stylistic trait specific to many contemporary rap and rap-influenced pop songs, particularly those in slow tempo that build on a trap or "dembow" beat's fundament. ${ }^{38}$ For example, Post Malone, Drake, Juice WRLD, Bad Bunny, and many German rappers often commence their vocal hooks by filling the "verbal space" (see Griffith, 2003, p. 45) with a continuous, dense row of rapidly succeeding syllables shaping either a one-note melody or a conjunct motion. ${ }^{39}$ From a nuance perspective, the short tones within

\footnotetext{
${ }^{37}$ One can see a spectral-analysis-based visualization of the single voice's most prominent partials.

${ }^{38}$ In reviews of Fugazi's music, some people describe Picciotto's delivery as "rapping" or "toasting". However, I want to make it clear that I do not intend to create a direct linkage from Fugazi to current rap music here. Initially, the Fugazi example was part of my doctoral dissertation (Steinbrecher 2016), in which I developed some of the analytical approaches applied in the examinations of this article.

${ }^{39}$ For example: Post Malone: "Better Now" (verse and chorus), "rockstar" (see below), "Congratulations" (chorus); Drake: "God's Plan" (first verse), "In My Feelings" (first verse), "Tootsie Slide" (prechorus); Juice WRLD: "Bandit" (verse), "Lucid Dreams" (verse); Bad Bunny: "Yo Perreo Sola" (verse, 0:41), "Callaita" (verse and chorus), "Safaera" (chorus); Samra \& Capital Bra: "Wieder Lila" (see below); Capital Bra: “Capital Bra je m’appelle” (verse and chorus), "Prinzessa” (verse and cho-
} 
these "barrages" (Greene, 2015) ${ }^{40}$ usually intertwine fluently and legato -as opposed, e.g., to the more aggressive and "choppy" delivery in "Turnover"due to the tones' pronounced sustain that, in many cases, results from the extensive use of voice-manipulating effects such as auto-tune. ${ }^{41}$

The significance of nuances here is that microtonal motion, friction, and ambiguity, such as in "Stressed Out", as well as microrhythmic deviations and articulatory variations are rather avoided or eliminated. Thus, these fast eighth- or sixteenth-note chains perform a threefold function: First, considering that the note onsets tend toward equidistance, they help regulate, following Duinker's observations on triplet flow (2019, p. 436), the temporal aspect of the song in that they compensate for the absence of regular hi-hat patterns; second, although the shape of the melodic contour is usually rather flat, it clearly can be comprehended and is "sing-alongable" nevertheless; and third, they function as anacrustic figures building up motional energy that is released at the end of the "barrages" through an elongated word that is similar or higher in pitch than the note before and succeeded by a downward movement.

For example, in the first chorus phrase of the 2017 hit "rockstar", 42 Post Malone chains 13 words together in less than three seconds, first clearly intonated on A\#, then clearly on "A", before he reaches the song's essential word, "rockstar". 43

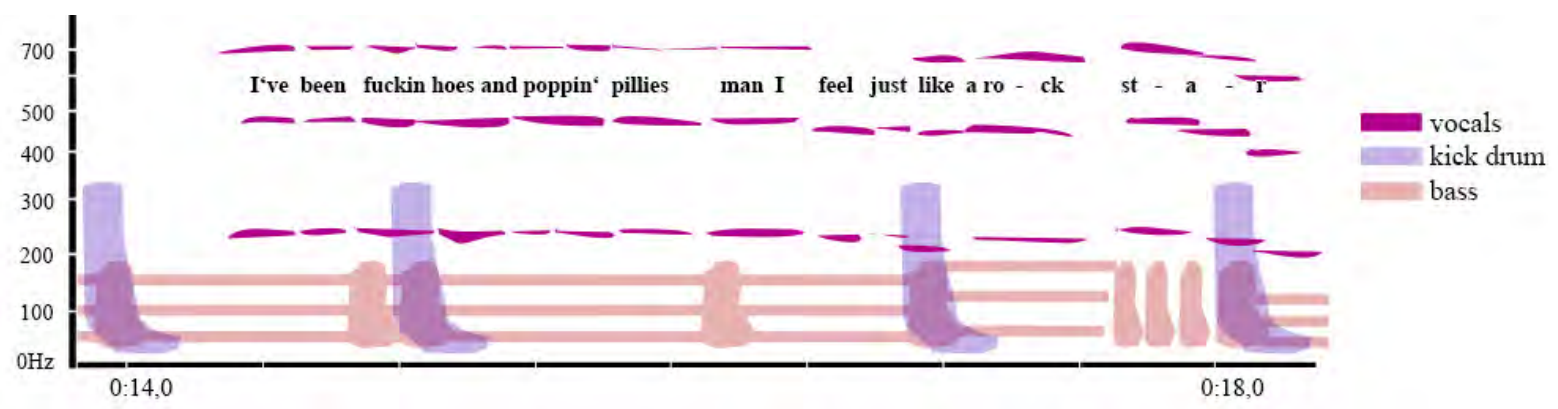

Figure 11. Vocal hook from "rockstar" (0:13,8-0:18,5; see also Appendix 9).

rus); Mero: "Wolke 10" (chorus), “Ferrari” (featuring ENO) (verse); Apache 207: "Bläulich" (verse and chorus).

${ }^{40}$ Greene describes Drake's early rapping style as: "Drake's delivery, meanwhile, was a barrage of eighth notes, each syllable exactly the length of the one before it".

${ }^{41}$ As Moylan remarks, the auto-tune effect particularly affects the sustain and leaves the beginnings and endings of pitches unaltered (2020, p. 132).

${ }^{42}$ Post Malone. 2017. rockstar. On Beerbongs \& Bentleys [MP3 file]. Republic Records. Amazon.com Song ID: 296684691.

43 "rockstar" as well as in below-discussed "Wieder Lila" obviously employ vocal effects such as autotune. 
Malone separates the two syllables of "rockstar" by a rest of approximately $100 \mathrm{~ms}$, moves up a halftone from A ("ro-ck") to A\# ("st-"), then descends stepwise to A ("a-") and the downbeat on G ("-r"). This downward movement on the upbeat is reinforced by a triplet impulse from the bass.

In another example, the 2019 German-chart-topping song "Wieder Lila" by Samra \& Capital Bra, ${ }^{44}$ the vocal hook is divided into two such "at-theend-stretched" patterns.

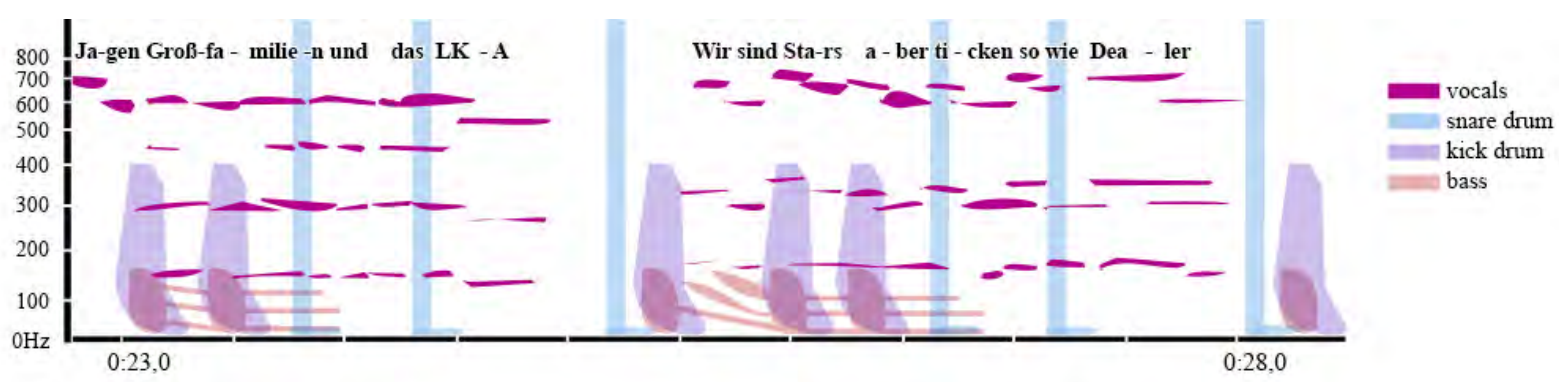

Figure 12. Vocal hook from "Wieder Lila” (0:22,7-0:28,5; see also Appendix 10).

The first part progresses similar to "rockstar", melodically very linear, with dense repetitions mostly on D toward the stressed vowel in the acronym "LK-A". The second part is slightly more erratic, as it quickly alternates between $\mathrm{D}$ and $\mathrm{E}$. It concludes in the sustained two syllables of the crossrhyme word "Dea-ler", which descends from F to D and is given a lot of space in the overall texture.

In these two rap songs, the descending leaps and elongated words are articulated sharply without glides or microtonal fluctuations and, thus, cut off the preceding, continuous flow rather abruptly. In other comparable songs, such as Drake's “God's plan” (2018; first verse) and Post Malone's "Better Now" (2018), the release of energy at the end of the "barrages" is done more smoothly, in that glides weaken the tonal motions. In "Better Now", the elongated words are emphasized additionally with a fast vibrato effect typical of Post Malone, which is a good example of how microtonal fluctuations also can be used as a trademark sound.

My last example concerns Ariana Grande's vocal delivery on her 2018 pop hit "thank u, next", ${ }^{45}$ which subtly intertwines currently trending rap

\footnotetext{
${ }^{44}$ Capital Bra \& Samra. 2019. Wieder Lila [MP3 file]. Urban. Amazon.com Song ID: 200000318148323

${ }^{45}$ Ariana Grande. 2018. thank $u$, next. On thank $u$, next [MP3 file]. Republic Records. Amazon.com Song ID: 200000305460507.
} 
techniques of pushing and pulling vocal lines. As a pop singer renowned for her singing abilities, she combines "scotch snap" patterns, ${ }^{46}$ triplet flow, and aforementioned contract-stretch phrasing with the deliberate use of microtonal and rhythmic inflections. Her melody phrases in the verse are subdivided into four segments that contain the latter two stylistic traits.

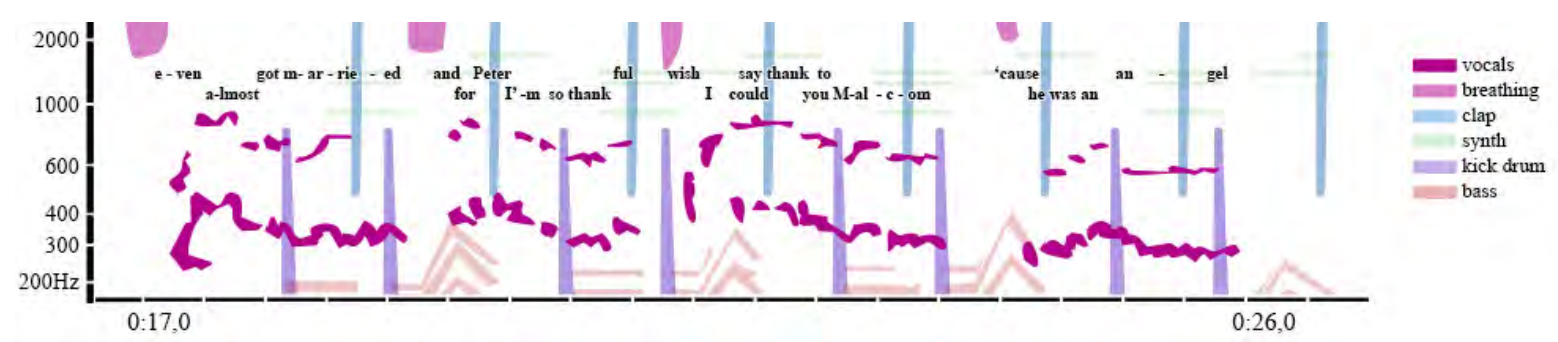

Figure 13. Vocal hook from "thank u, next" (0:16,7-0:25,9; see also Appendix 11).

For example, in the second phrase of the first verse, Grande uses a triplet flow to structure her small, melodic arch motives ("x-e-ven/al-most-got/ mar-x-ried") and to land on the two-syllable alliterations ("mar-ried", "Mal-colm") and assonances ("thank-ful", "an-gel"). The singer elongates the first, third, and fourth melody stopovers considerably, moving in a straight line or downward and adding a (natural) vibrato to them. The second stopover acts as a contrast in that the melodic grouping's final tone is roughly cut after an upward motion ("thank-ful"), creating a quick moment of tension directed toward the subsequent grouping. A similar small-scale variation structure is maintained in other verse phrases as well. All of these melodic cells are preceded by clearly audible, snatchy breathing noises from Grande, which function as kind of an anacrustic microrhythmic push. Another reason for her breathing being preserved in the mix might be to foreground her (allegedly) unadulterated, intimate vocal expression.

\section{Discussion and outlook}

This article aimed to foreground and conceptualize musical nuances in the context of contemporary Western popular music, with a particular focus on subtle processes that happen within tone-to-tone successions in mainstream popular music's hooks. Inspired by theories from cognitive psychology, philosophy, and "process-oriented" music theory, my analytical approach was guided by the idea that rhythmic and melodic nuances affect

${ }^{46} \mathrm{An}$ on-beat sixteenth note followed by a dotted eighth note (Temperley and Temperley, 2011). 
our aesthetic experience of tensity and motion via processes entailing anticipation, expansion, acceleration, and their corresponding opposites. In my song analyses, I exemplified my proposal of an integrated perspective that brings together rhythmic and melodic micro-variations under a single concept and suggested notational and analytical techniques adapted to it.

Such an entangled nuance concept appears to me particularly important in regard to music which has to operate within a rather narrow tonal, rhythmic, and durational frame to attract and "hook" a large and diverse (mass) audience in correspondence with currently circulating trends and an artist's image construction. In music that is created to be commercialized for as many international (particularly European and US-American) listeners as possible, there is only limited room for playing with and against established rhythmic and melodic schemas of expectation in Western popular music culture. This rather precludes, e.g., strong microrhythmic deviations on a structural level or permanent microtonal deviations (the musicians/ producers have to deal with nuances in a nuanced way, so to say). Thus, the nuance-related aesthetic particularities of mainstream popular music phrases might be found literally in detail, like in the temporal-processual interrelations that I have outlined in this article.

Given that modern digital music technology plays a central role in the music's creation, it becomes even more plausible to direct the attention more strongly to the aesthetic results of nuance-related actions and omissions. Extant software provides a broad range of possibilities for precisely, non-destructively, and directly working with and/or manipulating musical nuances. Due to sophisticated and user-friendly graphical interfaces and music-visualization tools, professional musicians/producers are able to freely and intentionally remove, retain, add, shift, or emphasize microrhythmic and -tonal subtleties in any possible manner. Thus, they have gained significant creative control over nuances, enabling to shape and combine them according to their intuitive evaluation of what suits a certain song, artist, or style.

However, having in mind the manifold ways in which those subtleties appear all across mainstream popular music's many different (and ever-changing) forms, respective analysis will certainly remain limited to interpreting case studies and, potentially, depict tendencies similar to the above-mentioned observations in regard to current rap productions. 


\section{Bibliography}

" Abraham, O. and von Hornbostel, E. M. (1910). Vorschläge für die Transkription exotischer Melodien. In M. Seiffert (Ed.). Sammelbände der internationalen Musikgesellschaft, 11(1909-1910) (pp. 1-25). Leipzig: Breitkopf \& Härtel.

»Adams, K. (2019). Musical Texture and Formal Instability in Post-Millenial Popular Music: Two Case Studies. Intégral, 33, 33-45.

» Ahlers, M. (2019). 'Kollegah the Boss': A case study of persona, types of capital, and virtuosity in German gangsta rap. Popular Music, 38(3), 457-480. Doi: $10.1017 /$ S0261143019000473

"Attas, R. (2015). Form as Process: The Buildup Introduction in Popular Music. Music Theory Spectrum, 37(2).

» Auslander, P. (2009). Musical Persona. The Physical Performance of Popular Music. In D. Scott (Ed.). The Ashgate Research Companion to Popular Musicology (pp. 303-315). Farnham: Ashgate.

» Baker, S. (2013). Teenybop and the Extraordinary Particularities of Mainstream Practice. In S. Baker, A. Bennett and J. Taylor (Eds.). Redefining Mainstream Popular Music (pp. 14-24). London: Routledge.

»Berlyne, D. E. (1971). Aesthetics and Psychobiology. New York: AppletonCentury-Crofts.

» Berry, W. (1987). Structural Functions in Music. Englewood Cliffs, N.J.: Prentice-Hall.

» Bowman, R. (1995). The Stax sound: a musicological analysis. Popular Music 14(3), 285-320.

» Brackett, D. (2000). Interpreting Popular Music. Cambridge: Cambridge University Press.

»Bresin, R. and Friberg, A. (2000). Emotional Coloring of Computer-Controlled Music Performances. Computer Music Journal, December 2000, 44-63. Doi: 10.1162/014892600559515

» Brockhaus, I. (2017). Kultsounds. Die prägendsten Klänge der Popmusik 19602014. Bielefeld: Transcript.

» Budde, D. (1997). Take Three Chords. Punkrock und die Entwicklung zum American Hardcore. Karben: Coda.

»Bugos, J. A., Heller, J. and Batcheller, D. (2014). Musical Nuance Task Shows Reliable Differences Between Musicians and Nonmusicians. Psychomusicology: Music, Mind, and Brain, 24(3), 207-213.

»Butler, M. J. (2006). Unlocking the Groove: Rhythm, Meter, and Musical Design in Electronic Dance Music. Bloomington: Indiana University Press.

»Butterfield, M. (2006). The Power of Anacrusis: Engendered Feeling in 
Groove-Based Musics. Music Theory Online 12(4).

" Butterfield, M. (2010). Variant Timekeeping Patterns and Their Effects in Jazz Drumming. Music Theory Online 16(4).

» Butterfield, M. (2011). Why Do Jazz Musicians Swing Their Eight Notes?. Music Theory Spectrum, 33(1), 3-26. Doi: 10.1525/mts.2011.33.1.3

»Chadwin, D. J. (2019). Applying microtonality to pop songwriting: A study of microtones in pop music. (Master's thesis). University of Huddersfield, Huddersfield, United Kingdom.

"Chew, G. (2001). Articulation and phrasing. Grove Music Online. Doi: 10.1093/gmo/9781561592630.article.40952

»Clarke, E. F. (1987). Categorical Rhythm Perception: An Ecological Perspective. In A. Gabrielsson (Ed.). Action and Perception in Rhythm and Music (pp. 19-34). Stockholm: Royal Swedish Academy of Music Publication.

"Clune, M. (2013). Writing Against Time. Stanford: Stanford University Press.

" Crowder, R. (1993). Auditory Memory. In S. McAdams and E. Bigand (Eds.). Thinking in Sound: The Cognitive Psychology of Human Audition (pp. 113146). Oxford: Oxford University Press.

»Cutting, C. (2018). Microtonal Analysis of "Blue Notes" and the Blues Scale. Empirical Musicology Review 13(1-2).

»Daley, M. (2007). Vocal Performance and Speech Intonation: Bob Dylan's "Like a Rolling Stone". Oral Tradition 22(1), 84-98.

"Danielsen, A. (2006). Presence and Pleasure - the funk grooves of James Brown and Parliament. Middletown, Conn.: Wesleyan University Press.

» Danielsen, A. (2010a). Here, there and everywhere: three accounts of pulse in D'Angelo's “Left and Right". In Musical Rhythm in the Age of Digital Reproduction (pp. 19-36). London: Routledge.

»Danielsen, A. (2010b). Introduction: Musical Rhythm in the Age of Digital Reproduction. In Musical Rhythm in the Age of Digital Reproduction (pp. 118). London: Routledge.

»Danielsen, A. (2016). TIME: Timing and Sound in Musical Microrhythm. (Project description). Retrieved from https://www.hf.uio.no/ritmo/english/ projects/time/time_projectdescription.pdf

»de Clercq, T. (2020). Popular Music Analysis Too Often Neglects the Analysis of Popular Music. (Review article). Popular Music, 39(2), 339-344.

» de la Motte-Harber, H. (1996). Handbuch der Musikpsychologie. Laaber: Laaber.

»Doll, C. (2017). Hearing Harmony: Toward a Tonal Theory for the Rock Era. Michigan: University of Michigan Press.

»Duinker, B. (2019). Good Things Come in Threes: Triplet Flow in Recent Hip-Hop Music. Popular Music, 38(3), 423-456. Doi: 10.1017/ S026114301900028X

»Elflein, D. (2010). Schwermetallanalysen. Die musikalische Sprache des Heavy 
Metal. Bielefeld: Transcript.

"Everett, W. (2009). The Foundations of Rock: From "Blue Suede Shoes" to "Suite: Judy Blue Eyes". New York: Oxford University Press.

» Fay, T. (1974). Context Analysis of Musical Gesture. Journal of Music Theory 18(1), 124-151.

»Forrest, D. (2017). PL Voice Leading and the Uncanny in Pop Music. Music Theory Online, 23(4).

» Frith, S. (1998). Performing Rites: On the Value of Popular Music. Oxford: Oxford University Press.

»Frühauf, J. and Kopiez, R. (2013). Music on the Timing Grid. The Influence of Microtiming on the Perceived Groove Quality of a Simple Drum Pattern Performance. Musicae Scientiae, 17(2), 246-260.

»Fuß, H.-U. (2005). Musik als Zeitverlauf. Prozeßorientierte Analyseverfahren in der amerikanischen Musiktheorie. Zeitschrift der Gesellschaft für Musiktheorie, 2(2-3), 21-34.

» Gabrielsson, A. (1995). Expressive Intention and Performance. In R. Steinberg (Ed.). Music and the Mind Machine: The Psychophysiology and the Psychopathology of the Sense of Music (pp. 35-47). Berlin: Springer Verlag.

" Geringer, J. M., Macleod, R., Madsen, C. and Droe, K. (2006). The Effect of Articulation Style on Perception of Modulated Tempo. Journal of Research in Music Education, 54(4), 324-336. Doi: 10.1177/002242940605400405

》 Geringer, J. M. and Sasanfar, J. K. (2013). Listener Perception of Expressivity in Collaborative Performances Containing Expressive and Unexpressive Playing by the Pianist. Journal of Research in Music Education, 61, 160-174. Doi: $10.1177 / 0022429413485246$

》 Gerischer, C. (2010). Groove - magische Momente - Versuch einer rationalen An- näherung. PopScriptum, 11. Retrieved from https:// edoc.hu-berlin.de/bitstream/handle/18452/21065/pst11_gerischer. pdf?sequence $=1 \&$ isAllowed $=y$

» Godøy, R. I. (2010). Gesture Affordance of Musical Sound. In R. I. Godøy and M. Leman (Eds.). Musical Gestures: Sound, Movement, and Meaning (pp. 103125). New York: Routledge.

» Greene, J. (2015). Evolve With the Flow: How Drake and Kendrick Found Their Voices. Pitchfork. Retrieved from https://pitchfork.com/features/ overtones/9623-evolve-with-the-flow-how-drake-and-kendrick-found-theirvoices/

»Green, L. (2002). How Popular Musicians Learn. A Way Ahead for Music Education. Aldershot: Ashgate.

» Griffiths, D. (2003). From Lyric to Anti-Lyric: Analyzing the Words in Pop Song. A. F. Moore (Ed.). Analyzing Popular Music (pp. 39-59). Cambridge: Cambridge University Press.

» Griffiths, P., Lindley, M. and Zannos, I. (2001). Microtone. Grove Music Online. 
Doi: $10.1093 /$ gmo/9781561592630.article.18616

»Hähnel, T., Marx, T. and Pfleiderer, M. (2014). Methoden zur Analyse der vokalen Gestaltung populärer Musik. Samples, 12. Retrieved from http:// www.gfpm-samples.de/Samples12/haehneletal.pdf

» Hansen, K. A. (2019). (Re)Reading Pop Personae: A Transmedial Approach to Studying the Multiple Construction of Artist Identities. Twentieth-Century Music 16(3), 501-529. Doi: 10.1017/S1478572219000276

»Hart, A. (2016). Microtonal Tunings in Electronic Dance Music: A Survey of Precedent and Potential. Contemporary Music Review, 35(2), 242-262. Doi: 10.1080/07494467.2016.1221635

» Hasty, C. (1997). Meter As Rhythm. New York and Oxford: Oxford University Press.

» Hennig, H., Fleischmann, R., Fredebohm, A., Hagmayer, Y., Nagler, J., Witt, A., Theis, F. and Geisel, T. (2012). The Nature and Perception of Fluctuations in Human Musical Rhythms. PLOS ONE, 7(4). Doi: 10.1371/annotation/ f0a4c12c-ebef-4b55-9beb-2ca30749965e

» Herbst, C., Hertegard, S., Zangger-Borch, D. and Lindestad, P.-Å. (2016). Freddie Mercury-Acoustic Analysis of Speaking Fundamental Frequency, Vibrato, and Subharmonics. Logopedics Phoniatrics Vocology, 42(1), 29-38. Doi: 10.3109/14015439.2016.1156737

» Higgins, K. (1997). Musical Idiosyncrasy and Perspectival Listening. In J. Robinson (Ed.). Music \& Meaning (pp. 83-102). Ithaca and London: Cornell University Press.

»Huber, A. (2013). Mainstream as Metaphor: Imagining Dominant Culture. In S. Baker, A. Bennett and J. Taylor (Eds.). Redefining Mainstream Popular Music (pp. 3-13). London: Routledge.

» Huber, M. (2018). Musikhören im Zeitalter Web 2.0. Theoretische Grundlagen und empirische Befunde. Wiesbaden: Springer.

» Iyer, V. (2002). Embodied Mind, Situated Cognition, and Expressive Microtiming in African-American Music. Music Perception, 19(3), 387-414.

" Johansson, M. (2010). Rhythm Into Style: Studying Asymmetrical Grooves in Norwegian Folk Music. (Ph.D. thesis). University of Oslo, Oslo, Norway.

" Jost, C. (2016). Musikalischer Mainstream. Aufgaben, Konzepte und Methoden zu seiner Erforschung. Pop. Kultur und Kritik, 8, 152-172.

» Juslin, P. N. (1997). Perceived Emotional Expression in Synthesized Performances of a Short Melody: Capturing the Listener's Judgment Policy. Musicae Scientiae, 2, 225-256.

» Juslin, P. N. (2003). Five Facets of Musical Expression: A Psychologist's Perspective on Music Performance. Psychology of Music, 31(3). Doi: 10.1177/03057356030313003

»Keil, C. (1994). Participatory Discrepancies and the Power of Music. In C. Keil and S. Feld (Eds.). Music Grooves (pp. 96-108). Chicago: University of Chicago 
Press.

»Kennick, W. E. (1961). Art and the Ineffable. Journal of Philosophy, 58(12), 309-320.

»Kilchenmann, L. and Senn, O. (2015). Microtiming in Swing and Funk Affects the Body Movement Behavior of Music Expert Listeners. Frontiers in Psychology/Performance Science, 6, 1-14.

» Klingmann, H. (2010). Groove - Kultur - Unterricht. Studien zur Erschließung einer musikkulturellen Praktik. Bielefeld: Transcript.

»Kubik, G. (2013). Blue Note. Grove Music Online. Doi: 10.1093/ gmo/9781561592630.article.A2234425

» Lindstrom, E., Juslin, P. N., Bresin, R. and Williamson, A. (2003). "Expressivity Comes from within Your Soul”: A Questionnaire Study of Music Students' Perspectives on Expressivity. Research Studies in Music Education, 20, 23-47. Doi: 10.1177/1321103X030200010201

" Martel, F. (2011). Mainstream. Wie funktioniert, was allen gefällt. München: Albrecht Knaus Verlag (transl. by E. Ranke and U. Schäfer).

» Meyer, L. B. (1956). Emotion and Meaning in Music. Chicago: Chicago University Press.

» Meyer, L. B. (1973). Explaining Music. Essays and Explorations. Berkeley: University of California Press.

» Middleton, R. (1990). Studying Popular Music. Milton Keynes: Open University Press.

》Moore, A. F. (1992). Patterns of harmony. Popular Music, 11(1), 73-106.

»Moore, A. F. (2012). Song Means. Analysing and Interpreting Recorded Popular Song. Farnham: Ashgate.

" Moylan, W. (2020). Recording Analysis. How the Record Shapes the Song. Abingdon and New York: Routledge.

» Narmour, E. (1990). The Analysis and Cognition of Basic Melodic Structures. Chicago: University of Chicago Press.

» Narmour, E. (1992). The Analysis and Cognition of Melodic Complexity: The Implication-Realization Model. Chicago: University of Chicago Press.

»Niketta, R. (1982). Kontrasteffekte in der Rezeption von Rockmusik mit unterschiedlicher Komplexität. Psychologische Beiträge, 24, 340-342.

»Pedersen, B. S. (2009). Anticipation and Delay as Micro-Rhythm and Gesture in Hip Hop Aesthetics. Journal of Music and Meaning, 8, 1-22.

»Peres, A. (2016). The Sonic Dimension as Dramatic Driver in 21st-Century Pop Music. (Ph.D. thesis). University of Michigan, Michigan, USA.

» Pfleiderer, M. (2003). Gestaltungsmittel populärer Musik. Versuch einer Systematik. Samples, 2. Retrieved from http://www.aspm-samples.de/ Samples2/pfleidep.pdf

»Pfleiderer, M. (2006). Rhythmus. Psychologische, theoretische und stilanalytische Aspekte populärer Musik. Bielefeld: Transcript. 
» Pfleiderer, M., Hähnel, T., Horn, K. and Bielefeldt, C. (Eds.). (2015). Stimme, Kultur, Identität: Vokaler Ausdruck in der populären Musik der USA, 19001960. Bielefeld: Transcript.

»Raffman, D. (1988). Toward a Cognitive Theory of Musical Ineffability. Review of Metaphysics, 41, 685-706.

» Raffman, D. (1993). Language, Music, and Mind. Cambridge, Massachusetts: MIT Press.

»Richards, M. (2017). Tonal Ambiguity in Popular Music's Axis Progressions. Music Theory Online, 23(3).

» Roholt, T. C. (2010). Musical Musical Nuance. The Journal of Aesthetics and Art Criticism, 69(1). Doi: 10.1111/j.1540-6245.2009.01387.x

»Scholz, H. (2014). Harmonik im musikalischen Mainstream der Jahre 2001 bis 2010. Untersuchungen zu den Top-10-US-R'n'B-/HipHop-Songs mit Sprechgesang. Berlin: LIT Verlag.

"Senn, 0. (2007). Die Analyse von Tonaufnahmen. Konzepte und Methoden zur musikwissenschaftlichen Analyse von Tonaufnahmen - dargestellt an Sarah Vaughans Einspielung des Musicalhits "My Favorite Things". (Ph.D. thesis). University of Zurich, Zurich, Switzerland.

》Sloboda, J. A. (2005). Exploring the Musical Mind: Cognition, Emotion, Ability, Function. Oxford and New York: Oxford University Press.

»Sloboda, J. A. and Juslin, P. N. (2005). Affektive Prozesse: Emotionale und ästhetische Aspekte musikalischen Verhaltens. In R. Oerter and T. Stoffer (Eds.). Allgemeine Musikpsychologie, Enzyklopädie der Psychologie, Band D/ VII/1 (pp. 767-841). Göttingen: Hogrefe.

»Snyder, B. (2000). Music and Memory. An Introduction. Cambridge: Massachusetts Institute of Technology Press.

»Spicer, M. (2017). Fragile, Emergent, and Absent Tonics in Pop and Rock Songs. Music Theory Online, 23(2).

»Stambaugh, J. (1964). Music as a Temporal Form. The Journal of Philosophy, 61(9), 265-280.

»Steinbrecher, B. (2016). Das Klanggeschehen in populärer Musik. Perspektiven einer systematischen Analyse und Interpretation. Wien-Köln-Weimar: Böhlau.

»Stockmann, D. (1979). Die Transkription in der Musikethnologie: Geschichte, Probleme, Methoden. In Acta Musicologica, 51, 204-245.

» Tagg, P. (2012). Music's Meanings - A Modern Musicology for Non-Musos. New York and Huddersfield: The Mass Media Music Scholars' Press.

» Taylor, J., Baker, S. and Bennett, A. (2013). Preface. In S. Baker, A. Bennett, and J. Taylor (Eds.). Redefining Mainstream Popular Music (pp. viii-xiv). London: Routledge.

» Temperley, N. and Temperley, D. (2011). Music-Language Correlations and the "Scotch Snap". Music Perception 29(1), 51-63. Doi: 10.1525/ mp.2011.29.1.51 
" Temperley, David and Trevor de Clercq. 2013. "Statistical Analysis of Harmony and Melody in Rock Music". Journal of New Music Research, 42(3), 187-204.

» Thies, W. (1982). Grundlagen einer Typologie der Klänge. Hamburg: Karl Dieter Wagner.

"Thomson, W. (1983). Functional Ambiguity in Musical Structures. Music Perception 1(1), 3-27.

» Toynbee, J. (2002). Mainstreaming, from Hegemonic Centre to Global Networks. In D. Hesmondhalgh and K. Negus (Eds.). Popular Music Studies (pp. 149-163). London: Hodder Arnold.

»Traut, D. (2005). "Simply Irresistible". Recurring Accent Patterns as Hooks in Mainstream 1980s Music. Popular Music, 24, 57-77.

» von Appen, R. and Frei-Hauenschild, M. (2012). AABA, Refrain, Chorus, Bridge, PreChorus - Songformen und ihre historische Entwicklung. In D. Helms and T. Phleps (Eds.). Black Box Pop. Analysen Populärer Musik (pp. 57124). Bielefeld: Transcript.

» von Appen, R., Doehring, A., Helms, D. and Moore, A. F. (2015). Introduction. In Song Interpretation in 21st-Century Pop Music (pp. 1-8). Farnham: Ashgate.

»Weisbard, E. (2014). Top 40 Democracy: The Rival Mainstreams of American Music. Chicago: University of Chicago Press.

”Wicke, P. (2003). Popmusik in der Analyse. Acta Musicologica, 75, 107-128.

»Winkler, P. (1997). Writing Ghost Notes: The Poetics and Politics of Transcription. In D. Schwarz, A. Kassabian and L. Siegel (Eds.). Keeping Score: Music, Disciplinarity, Culture (pp. 169-203). Charlottesville and London: University Press of Virgina. 


\section{Appendix}

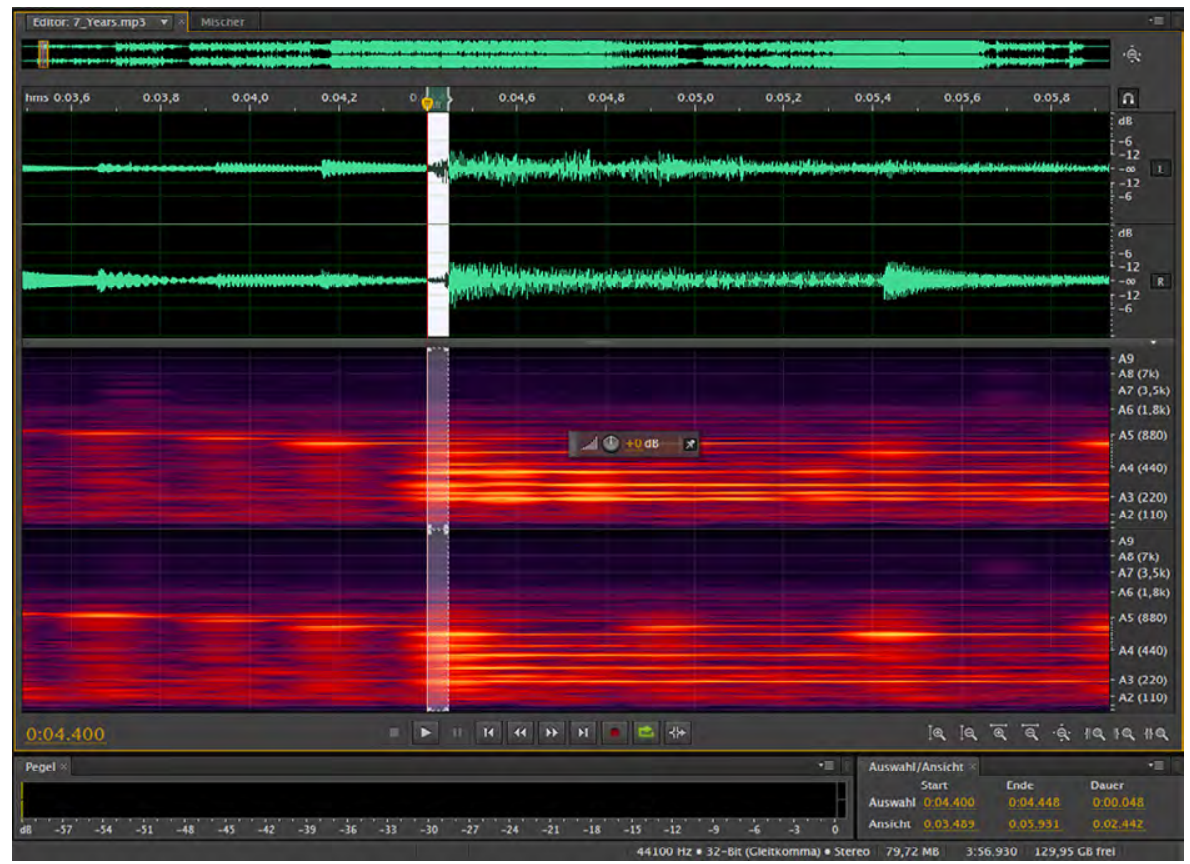

Appendix 1: “7 Years” piano hook, waveform and sonogram (selection on downbeat).

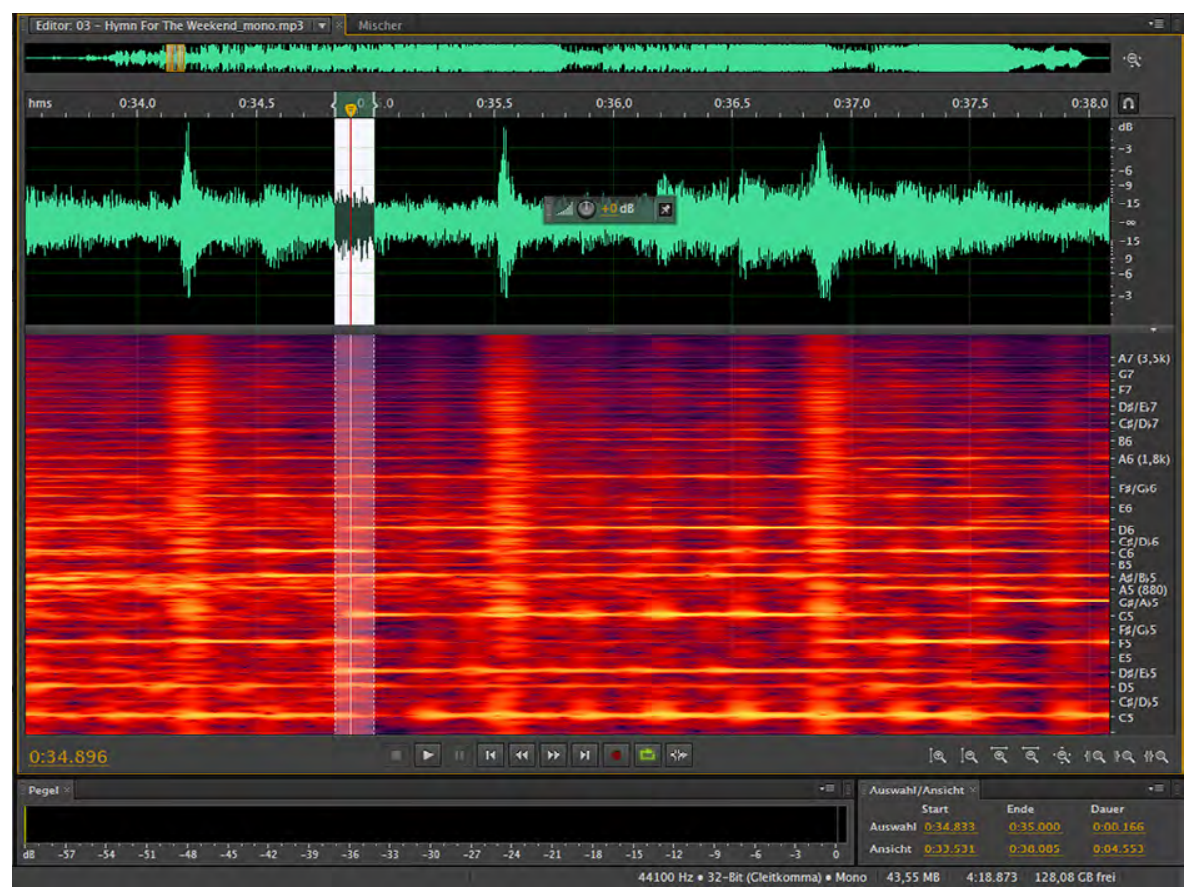

Appendix 2: "Hymn For The Weekend" piano hook, waveform and sonogram (selection on offsetarticulation). 


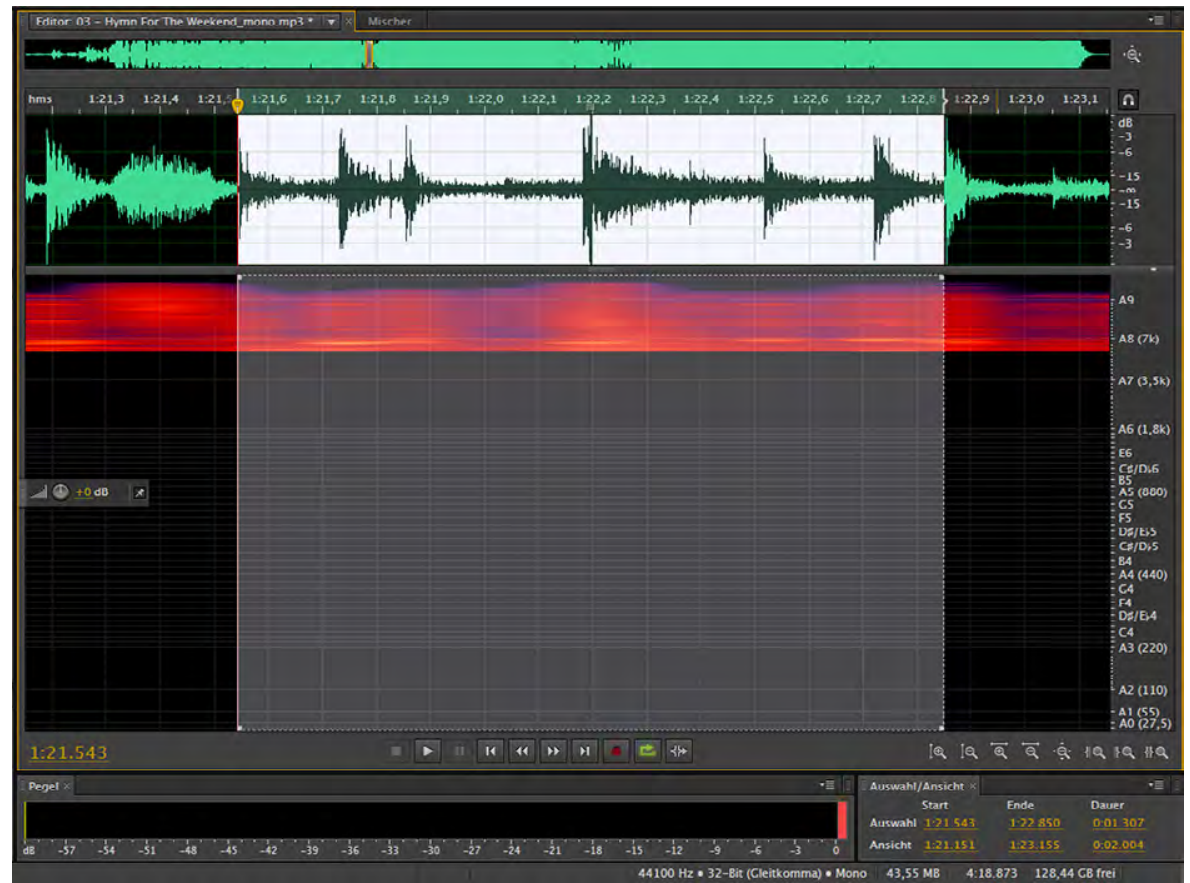

Appendix 3: "Hymn For The Weekend" shuffle pattern, waveform and sonogram (selection on filtered shuffle pattern).

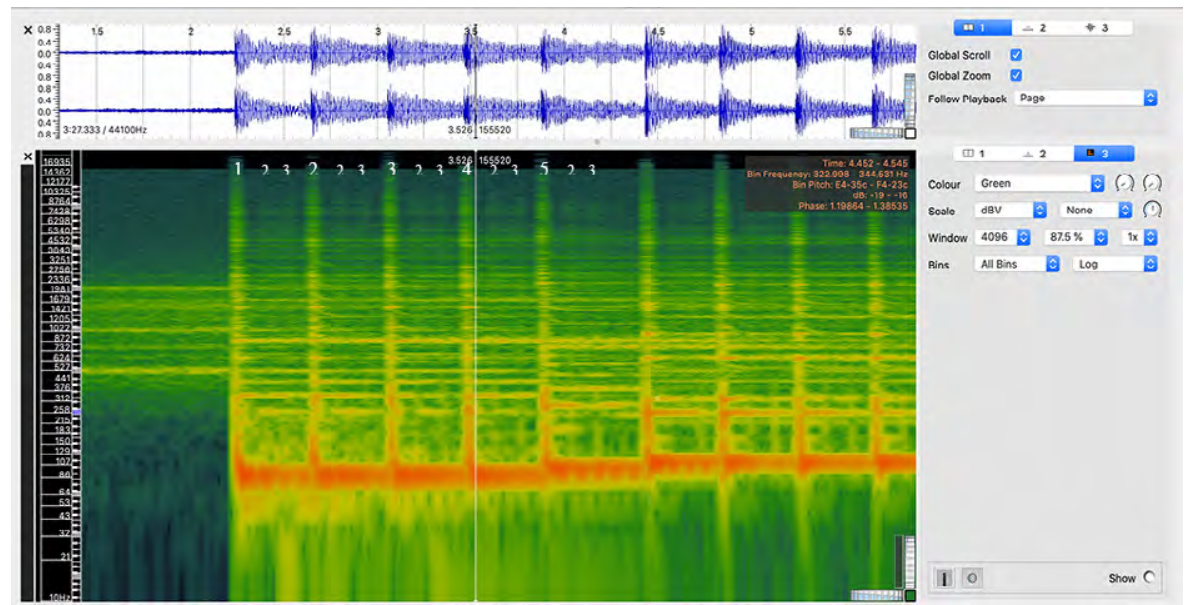

Appendix 4: “This One's For You” delay structure, waveform and sonogram. 


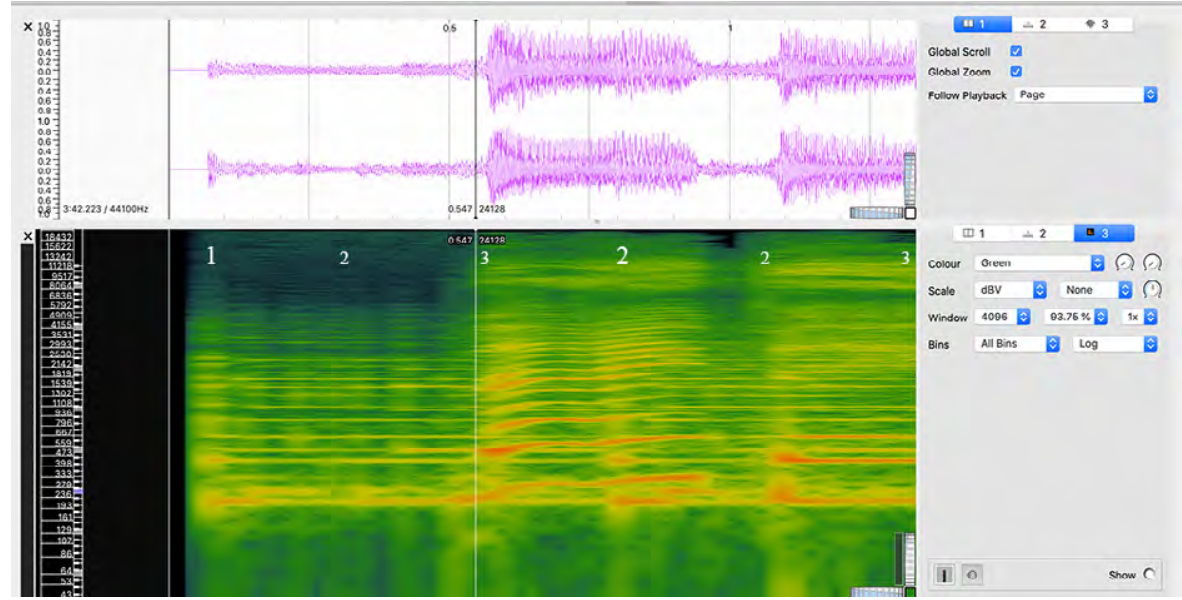

Appendix 5: "This Is What You Came For" synth arpeggio and vocal slide, waveform and sonogram.

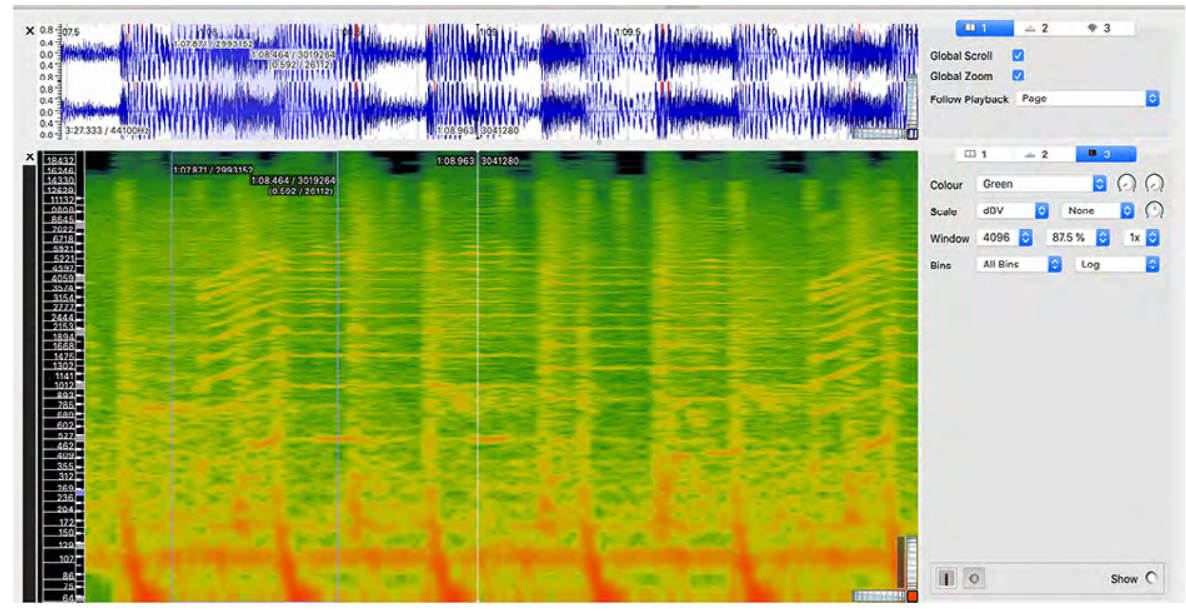

Appendix 6: "This One’s For You" synth hook slide, waveform and sonogram. 


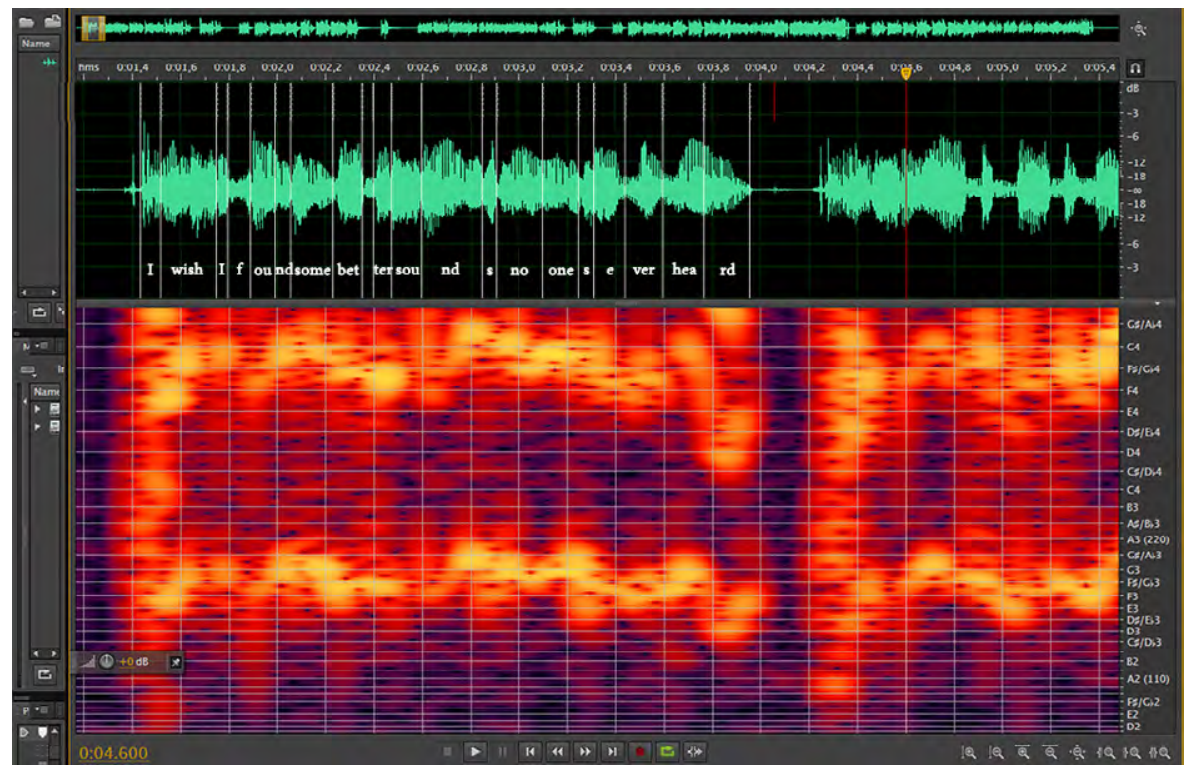

Appendix 7: "Stressed Out" vocal hook, waveform and sonogram (vocals-only).

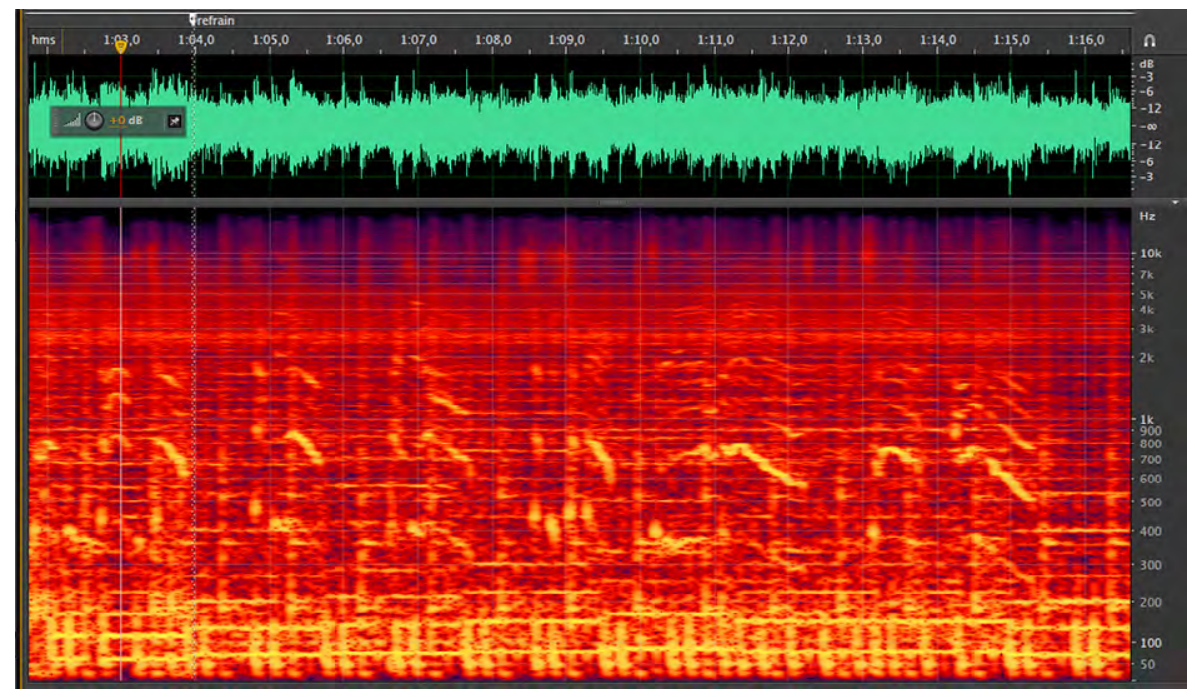

Appendix 8: "Turnover" vocal hook, waveform and sonogram. 


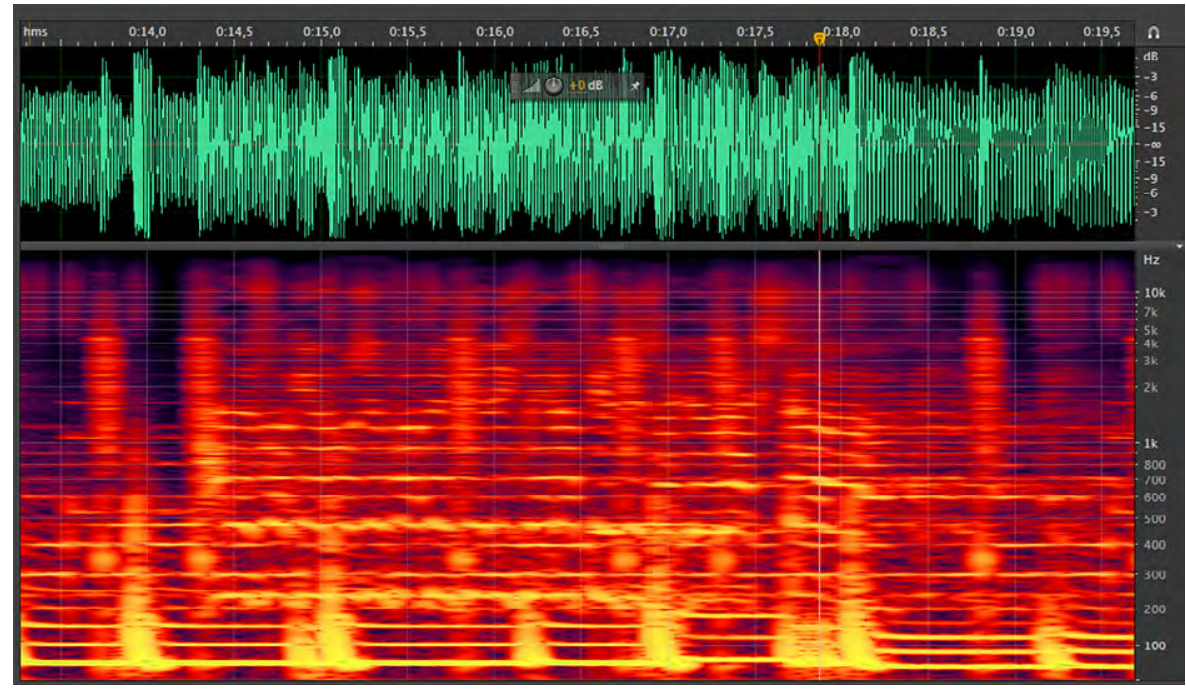

Appendix 9: A "rockstar" vocal hook, waveform, and sonogram.

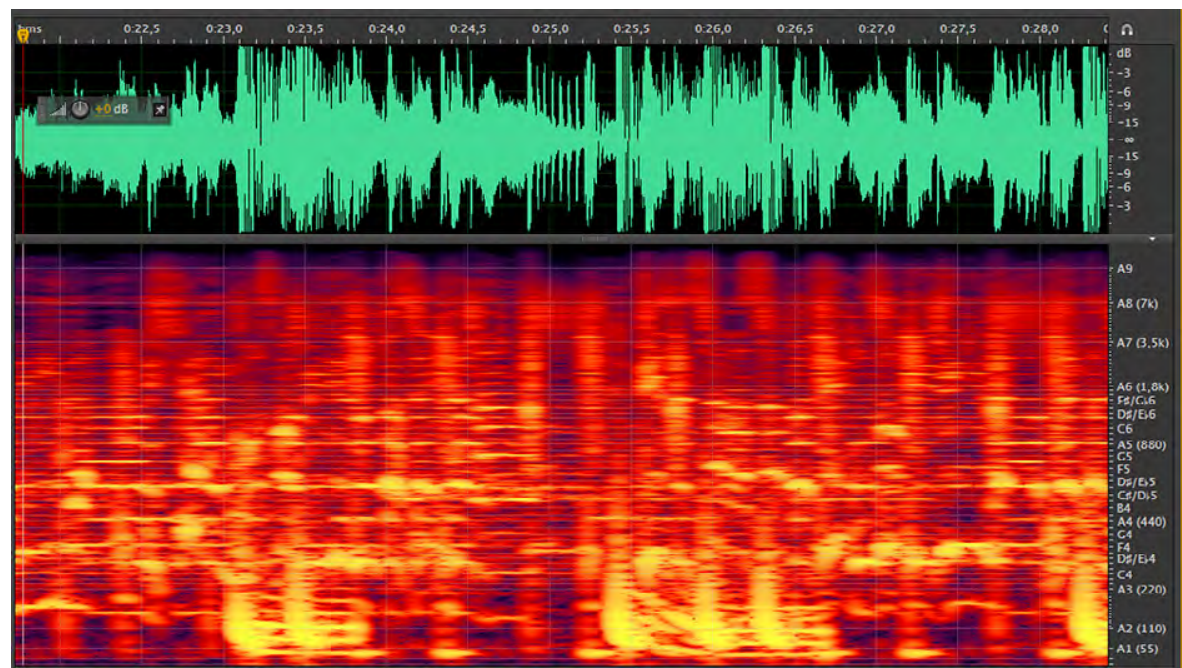

Appendix 10: “Wieder Lila” vocal hook, waveform and sonogram. 


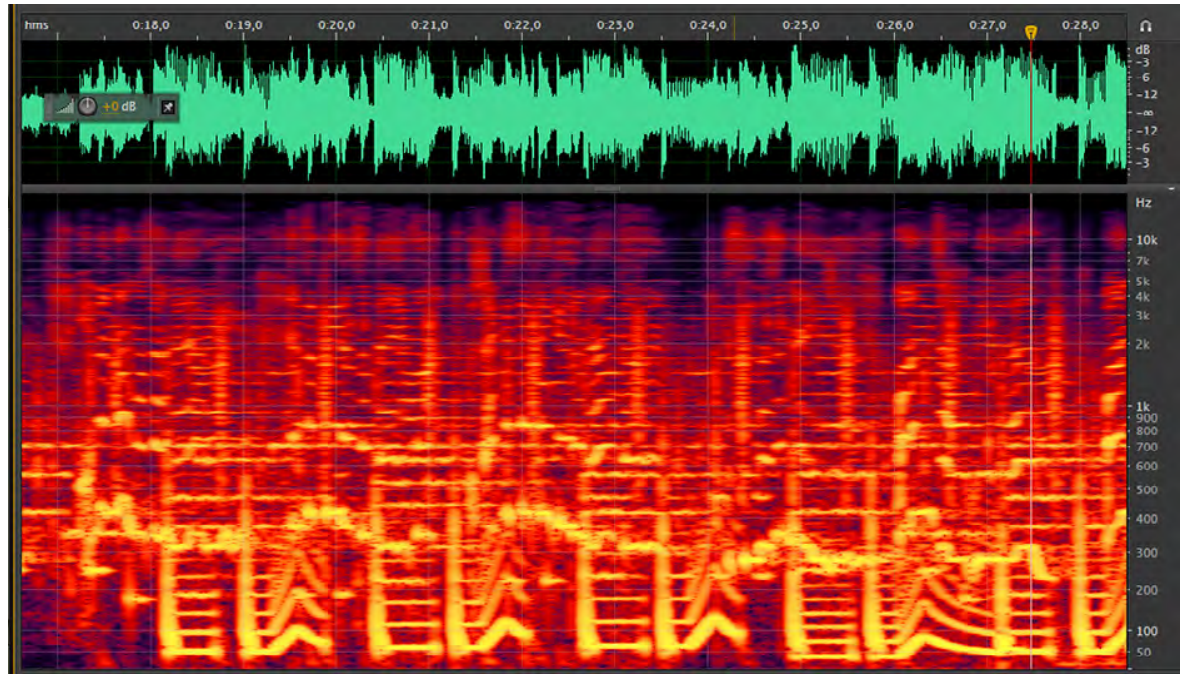

Appendix 11: "thank u, next" vocal hook, waveform and sonogram.

\section{Biography / Biografía / Biografia}

\section{Bernhard Steinbrecher}

Is post-doc researcher and lecturer in popular music at the Music Department of the University of Innsbruck, Austria. He holds a Ph.D. in musicology from the University of Music Weimar, Germany. His main scholarly fields of interest are musical analysis, theory, history, and reception practices of popular music, particularly regarding notions of mainstream music, and the relation between its sounds and social, psychological, and aesthetic questions. Steinbrecher's monography about the analysis and interpretation of popular music was published in 2016. He is member of the executive committee of the International Association for the Study of Popular Music (IASPM) and has been teaching at the Universities of Vienna, Salzburg, and Innsbruck. 